\title{
Supervision, support and mentoring interventions for health practitioners in rural and remote contexts: an integrative review and thematic synthesis of the literature to identify mechanisms for successful outcomes
}

\author{
Anna M Moran ${ }^{1 *}$, Julia Coyle ${ }^{1}$, Rod Pope ${ }^{1}$, Dianne Boxall ${ }^{1}$, Susan A Nancarrow ${ }^{2}$ and Jennifer Young ${ }^{1}$
}

\begin{abstract}
Objective: To identify mechanisms for the successful implementation of support strategies for health-care practitioners in rural and remote contexts.

Design: This is an integrative review and thematic synthesis of the empirical literature that examines support interventions for health-care practitioners in rural and remote contexts.

Results: This review includes 43 papers that evaluated support strategies for the rural and remote health workforce. Interventions were predominantly training and education programmes with limited evaluations of supervision and mentoring interventions. The mechanisms associated with successful outcomes included: access to appropriate and adequate training, skills and knowledge for the support intervention; accessible and adequate resources; active involvement of stakeholders in programme design, implementation and evaluation; a needs analysis prior to the intervention; external support, organisation, facilitation and/or coordination of the programme; marketing of the programme; organisational commitment; appropriate mode of delivery; leadership; and regular feedback and evaluation of the programme.

Conclusion: Through a synthesis of the literature, this research has identified a number of mechanisms that are associated with successful support interventions for health-care practitioners in rural and remote contexts. This research utilised a methodology developed for studying complex interventions in response to the perceived limitations of traditional systematic reviews. This synthesis of the evidence will provide decision-makers at all levels with a collection of mechanisms that can assist the development and implementation of support strategies for staff in rural and remote contexts.
\end{abstract}

Keywords: Supervision, professional development, synthesis, mechanism, health practitioner, rural

\footnotetext{
*Correspondence: amoran@csu.edu.au

${ }^{1}$ Centre for Inland Health, Charles Sturt University, PO Box 789, Albury, NSW 2640, Australia

Full list of author information is available at the end of the article
} 


\section{Introduction}

An important goal of health services is to provide accessible, equitable and efficient health care. The delivery and organisation of rural health care has seen significant changes over the past decade [1]. These changes have dictated the need for a rural health workforce that is adaptable and equipped with the skills and knowledge to diversify service delivery models [2].

However, the ability of rural health services to support adequately skilled and adaptable health practitioners is hampered by a number of factors including: poor recruitment and retention of practitioners [3]; shortages of practitioners [3]; high clinical loads, particularly for sole practitioners [4]; limited access to formal mentoring or supervisory relationships [4]; poor relationships with management [4,5]; difficulty accessing professional development activities or continuing education $[4,5]$; limited access to relief to allow professional or service development $[4,6]$; limited career pathways; limited or no dedicated work time allocated for professional reading or study [7]; and new graduates and sole practitioners possessing limited skills in service development [6].

The positive impact of the content and educational techniques utilised for continuing medical education (CME) interventions [8-10], training interventions [11], supervision [12] and mentoring [13] on the competence of the health workforce has been demonstrated elsewhere. It is less clear, however, how and to what extent the contexts in which such interventions are delivered contribute to their effect on staff, service and even patient outcomes.

This is particularly the case for supporting health practitioners in rural and remote contexts where accessing, delivering and participating in appropriate support opportunities is influenced by the complexity of the rural and remote environment [14-16]. Professional or geographic isolation, lack of financial resources and the costs of travel, time away from work, and cover and relief are common factors limiting support for practitioners in rural and remote areas. As Cameron et al. (p. 6) summarise: 'Geographical location makes professional development a challenge, while isolation makes it essential for professional growth and peer support' [16].

Recent evidence shows that a therapist's decision to locate to, stay or leave a rural community is influenced by the availability of and access to practice supports, opportunities for professional growth, organisational commitment to supporting the practitioner and understanding the context of rural practice [17]. The need for more research to evaluate the effect of access to relevant continuing professional development (CPD) (as a form of support) on staff retention and, ultimately, rural healthcare outcomes has been acknowledged [18] in particular by the World Health Organisation (WHO). The WHO's policy of improving retention of rural health-care workers recommends that governments 'design continuing education and professional development programmes that meet the needs of rural health workers and that are accessible from where they live and work, so as to support their retention' [19].

However, the relation between the rural and remote context in which a support strategy is implemented and the mechanisms that facilitate or hinder the effect a support strategy can have on staff, services or patient outcomes has been poorly explored. The limitations of more traditional systematic review approaches in exploring issues in rural and remote health-care contexts have been established [20]. Therefore, using an integrative review and thematic synthesis of the literature, the aim of this paper is to identify: the range of support interventions reported in the literature for health-care practitioners in rural and remote contexts; how the success of support interventions is measured and defined; and the mechanisms that may contribute to the success of these interventions in rural and remote contexts. The use of an integrative review expands the variety of research designs that can be incorporated within a review's inclusion criteria and allows the incorporation of both qualitative and quantitative information [21].

For the purpose of this paper, we have chosen to use the term support to encompass a number of concepts that can be seen as models of professional support. Namely, we were interested in exploring support in terms of supervision, mentoring, professional development and more general support interventions (for example, the provision of locum relief, support from colleagues and networks of practitioners [22]). These concepts are considered potentially modifiable factors that can contribute to a healthcare practitioner's decision to leave or stay in rural practice [23]. The term professional support has also been recently utilised to examine the utility of a professional support framework that encompasses a suite including professional supervision, mentoring, peer group supervision, peer review, work shadowing, in-service programmes and journal clubs (p. 562) [24].

We acknowledge that traditional definitions of several of these concepts overlap with one another. Both supervision and mentorship, for example, can be seen as models of professional support. Hence, the scope of the interventions explored in this review is deliberately wide; however, the population (or contextual) focus, that of rural and remote health practitioners, is relatively narrow.

We envisage that by exploring the broader concept of support, we will identify an appropriate suite of mechanisms to support health practitioners in rural and remote contexts. 


\section{Methods}

Inclusion and exclusion criteria

Articles were included in this review if they empirically explored any intervention that was aimed at supporting health professionals in a rural or remote context. Specifically, the concept of support was explored in terms of support, supervision, professional development and mentoring (see Table 1 for a full list of search terms utilised). We limited our search to the period 1999 to 2012 as technological advances made since 1999, such as the development of the internet and laptops, have introduced new contexts in which support interventions for rural and remote practitioners are delivered, which we were keen to explore. Only those articles published in English language literature were included.

No report was excluded based on the data evaluation system described below; however, the strength of a paper was considered when reporting findings. When screening papers for inclusion we relied solely on the use of the terms 'rural' and 'remote' by the authors of the papers, although we acknowledge that the terms 'rural' and 'remote' can be explicitly defined using a more formal classification [25]. Where available we have detailed the authors' definitions of 'rural' and 'remote'.

\section{Search strategy}

Broad eligibility criteria were used to assist with problem identification [21] and the capture of the full extent of literature in this field. A research assistant (JY) searched the electronic, peer-reviewed literature for the period 1999 to 2012 using guidance from Booth [26]. Multiple databases were utilised in the search and are outlined, along with key search terms, in Table 1.

\section{Data evaluation}

After removal of duplicates, an initial review of titles and abstracts produced 2,743 results (Figure 1). To better focus the review, 50 abstracts were randomly selected and jointly reviewed by two researchers (AM and JY). A joint decision was made as to which studies were relevant to the study aims and which were not, resulting in the construction of a preliminary decision process (outlined in notes accompanying Figure 1). This was used to screen the remaining references. By focusing the review, the number of potentially relevant sources was reduced from 2,743 to 790 papers.

Five researchers then independently screened an allocated set of abstracts using a pro forma for screening (Table 2), reflecting the inclusion criteria outlined in Table 1. This process resulted in a final set of 46 full text articles, which were read and assessed for eligibility for inclusion in the review (Figure 1). A total of 43 articles were included in the final review.

The process for assessing quality is complex. Although a number of tools exist, there is no gold standard for

Table 1 Article identification process

\begin{tabular}{|c|c|}
\hline Process & Detail \\
\hline Sampling strategy & Selective: Sample databases from medicine, nursing, allied health and social science fields within specified limits \\
\hline Type of study & $\begin{array}{l}\text { All qualitative research (grounded theory, ethnography, action research, exploratory approaches, phenomenology), } \\
\text { quantitative research (randomised controlled trials, controlled clinical trials, controlled before and after studies, uncontrolled } \\
\text { before and after studies) and systematic reviews }\end{array}$ \\
\hline Approaches & Subject searches, citation searches, contact with authors \\
\hline Range of years & Beginning of 1999 to end of 2009. Updated in 2013 to include beginning of 2010 to end of 2013. \\
\hline Language & English \\
\hline \multirow[t]{2}{*}{$\begin{array}{l}\text { Inclusion and } \\
\text { exclusions }^{a}\end{array}$} & $\begin{array}{l}\text { Inclusion: Empirical research study of an intervention aimed at supporting }{ }^{b} \text { health professionals; involves rural and remote } \\
\text { populations; report evidence of outcomes related to staff, service or patients. }\end{array}$ \\
\hline & Exclusion: No abstract for review, article is a commentary piece, or editorial. \\
\hline \multirow[t]{9}{*}{ Terms used } & Mentor + health + rural OR remote \\
\hline & Professional support + health + rural OR remote \\
\hline & Supervision + health + rural OR remote \\
\hline & Professional development + health + rural OR remote \\
\hline & Continuing professional education + health + rural OR remote \\
\hline & Continuing medical education + health + rural OR remote \\
\hline & Preceptorship + health + rural OR remote \\
\hline & Medical + supervision + rural OR remote \\
\hline & Allied health + rural OR remote \\
\hline Electronic sources & CINAHL Plus, EBSCOhost Health, Informit, MEDLINE OvidSP, Cochrane Library, SCOPUS, ISI Web of Knowledge, BioMed Central \\
\hline
\end{tabular}

${ }^{a}$ Detailed in the decision tree of Table 2 ; ${ }^{b}$ support refers to professional development, supervision, mentoring, continuing education, assistance, encouragement and resources that contribute to clinical practice, service delivery and staff satisfaction. 


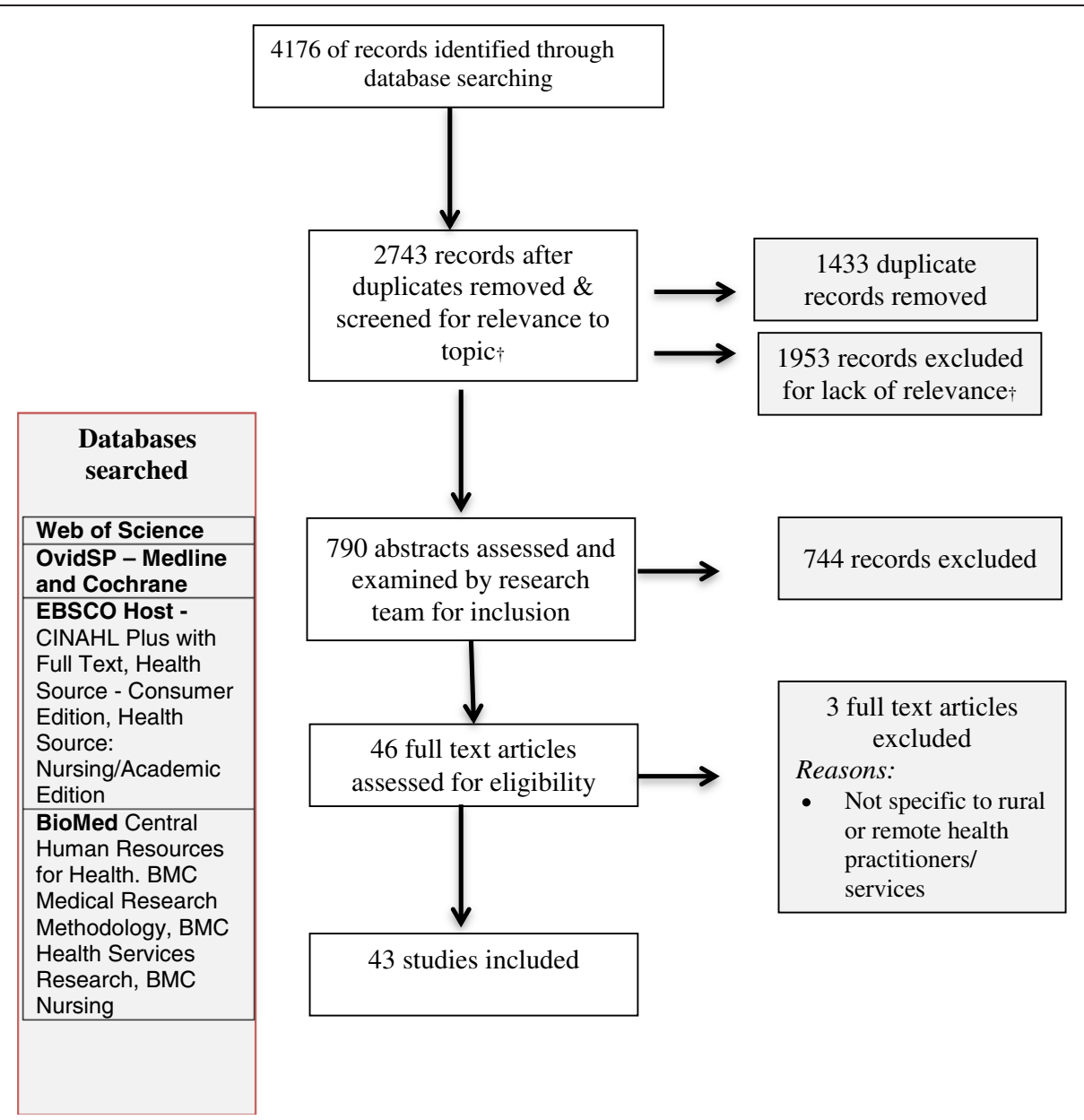

Figure 1 PRISMA flow chart of the integrative review. $†$ abstracts screened using the following inclusion criteria: must have abstract for review; must contain reference to supervision, support (professional development/education), mentoring; must examine issues related to health care practitioners (and not undergraduate students); must be empirical research (not commentary, discussion or editorial); must be rural, regional or remote.

Table 2 Process for abstract screening

\begin{tabular}{|c|c|c|c|}
\hline 1. Does the paper relate to supervision, professional support or mentoring? & Yes - go to 2 & No - exclude & Can't tell - exclude \\
\hline $\begin{array}{l}\text { 2. Does the paper describe a research study or evaluation (that is truly } \\
\text { empirical)? }\end{array}$ & Yes - go to 4 & No - go to 3 & Can't tell - go to 3 \\
\hline 3. Is it a systematic review? & Yes - go to 4 & $\begin{array}{l}\text { No - consider for } \\
\text { background }\end{array}$ & Can't tell - exclude \\
\hline \multicolumn{4}{|l|}{ 4. Context } \\
\hline $\begin{array}{l}\text { Does the study describe: development of the intervention or model } \\
\text { (input evaluation); implementation or actual intervention of the intervention } \\
\text { or model (process evaluation); or evaluation of the intervention or model } \\
\text { (impact evaluation)? }\end{array}$ & Yes - go to 5 & $\begin{array}{l}\text { No to all - consider } \\
\text { for background }\end{array}$ & $\begin{array}{l}\text { Can't tell - consider } \\
\text { for background }\end{array}$ \\
\hline \multicolumn{4}{|l|}{ 5. Outcomes } \\
\hline $\begin{array}{l}\text { Does the study analyse change in practitioner behaviour, service outcome } \\
\text { or patient outcomes (within a qualitative, quantitative or mixed } \\
\text { methods design? }\end{array}$ & Yes - go to 6 & $\begin{array}{l}\text { No to all - consider } \\
\text { for background }\end{array}$ & $\begin{array}{l}\text { Can't tell - get full } \\
\text { paper }\end{array}$ \\
\hline \multicolumn{4}{|l|}{ 6. Population } \\
\hline Does the study examine rural and remote areas AND health practitioners? & Yes - include & No - exclude & $\begin{array}{l}\text { Can't tell - get full } \\
\text { paper }\end{array}$ \\
\hline
\end{tabular}


calculating quality scores. The use of an integrative review with a thematic synthesis to extract a fuller understanding of 'relationships, mechanisms and meaning' within the evidence base [27] enables extraction of information from research that traditionally may not have been considered for review [21].

As we were primarily interested in qualitatively exploring and mapping the relations between the rural and remote context, the mechanisms of the support intervention and the outcomes of the support strategy, the magnitude of the effect of the intervention itself was not assessed. We therefore used thematic techniques to identify any evidence that linked mechanisms, specific to rural and remote contexts, to outcomes. As such, although the strength of evidence was examined, a quality assessment was not considered paramount to the identification of relations.

To broadly comment on the strength of the evidence utilised in this research, each study design was assessed according to its place in the research hierarchy using Daly et al.'s hierarchy of evidence for assessing qualitative research [28], the National Health and Medical Research Council (NHMRC) levels of evidence model for quantitative research [29] and mixed methods research was assessed using both Daly et al. and NHMRC levels of evidence for qualitative and quantitative components. Evidence hierarchies reflect 'the potential of each study included in the systematic review to adequately answer a particular research question, based on the probability that its design has minimised the impact of bias on the results' (p. 4) [29].

Given the mass of literature identified and the broad concepts explored, further additional hand searches of cited reference lists were not conducted nor were searches conducted within the grey literature or other sources.

\section{Data analysis}

Thematic analysis techniques (see below) were then applied to the literature in conjunction with conceptual mapping using the mind-mapping software Freeplane to identify: the range of support interventions; the impact these interventions have on patient, staff and service outcomes in order to define 'success' and the mechanisms specific to rural and remote contexts within which the identified interventions were applied that may be associated with successful outcomes.

Freeplane allows the hierarchical, conceptual mapping of a range of related concepts reflecting synthesis approaches described by Baxter et al. [30] and Mays et al. [31]. Specifically, the thematic analysis approach employed is most closely related to framework analysis [32], which involves a systematic process of familiarisation with the data, identifying a thematic framework, indexing the themes, charting those themes into a hierarchical framework and then mapping and interpreting those themes.

\section{Results}

This review identified 43 papers evaluating support strategies for the rural and remote health workforce (Tables 3 and 4). Papers were predominantly from Australia $(n=19)$, examining medical practitioners $(n=8)$ or nurses $(n=8)$ (Table 4).

\section{Evidence strength}

The strength of evidence was, overall, low with the majority of studies being either Level IV (NHMRC, quantitative evidence) or Level III (Daly et al., qualitative evidence) (Table 5). One randomised controlled trial (Level II) [42] and two Level I qualitative studies were identified [35,65].

The research was predominantly descriptive pre- and post-intervention evaluations using unvalidated questionnaires (Table 3). The most informative qualitative studies explored mechanisms for successful support interventions. For example, Lynch and Happell [33,34] examined the 'process and journey' of a clinical supervision implementation strategy for mental health workers in a rural health service.

\section{Support interventions}

Interventions were predominantly training and education programmes delivered face to face, remotely or utilising a combination of face-to-face delivery with technology. There were a limited number of evaluations specifically exploring supervision and mentoring interventions $(n=5)$. A number of papers explored a combination of support strategies (Tables 3 and 4).

Four categories of support were identified from the literature (Table 3 ), generally reflecting the key search terms. These included supervision strategies or interventions, professional support strategies, training and education interventions and mentoring strategies or interventions.

Supervision incorporates interventions primarily focussing on the delivery of a supervision programme or the implementation of a supervision strategy.

Training and education includes interventions involving training in a particular skill, for example, online training programmes for rural and remote mental health practitioners in cognitive behavioural therapy (CBT) [42], CPE, CME or CPD.

Professional support includes interventions that aim to support practitioners through 'connectedness' using networking and collaboration opportunities. It also includes strategies such as supporting practitioners to participate in planning to improve working conditions (for example, see Teasley et al. [38]) and changes in work structures 


\begin{tabular}{|c|c|c|c|c|}
\hline Citation & Design and quality & $\begin{array}{l}\text { Participants and geographic } \\
\text { location }\end{array}$ & Intervention and key contextual information & Outcome measures and findings \\
\hline \multicolumn{5}{|c|}{ Papers examining supervision } \\
\hline \multirow[t]{3}{*}{$\begin{array}{l}\text { Lynch and Happell } \\
\text { [33] }\end{array}$} & \multirow{2}{*}{$\begin{array}{l}\text { Qualitative - } \\
\text { 'exploratory' approach: } \\
\text { document analysis and } \\
\text { interviews }\end{array}$} & Nurses (in mental health) & $\begin{array}{l}\text { Intervention: Examination of the 'process and journey' } \\
\text { of a clinical supervision implementation strategy (part I) } \\
\text { (face to face) }\end{array}$ & $\begin{array}{l}\text { Primary measure: Service and staff outcomes - factors } \\
\text { identified that led to successful implementation of } \\
\text { clinical supervision models }\end{array}$ \\
\hline & & $\begin{array}{l}\text { Rural: Service examined has } \\
3,000 \text { registered clients } \\
\text { covering } 44,000 \mathrm{~km}^{2}\end{array}$ & \multirow{2}{*}{$\begin{array}{l}\text { Contextual information: Five key stages of } \\
\text { implementation were identified: Stage } 1 \text { - assessing } \\
\text { the organisational culture and exploration of } \\
\text { possibilities. Stage } 2 \text { - initial implementation strategy } \\
\text { (need for leadership via leadership group, addressing } \\
\text { issue with organisational culture, engagement of } \\
\text { external organisation to provide a four-day supervision } \\
\text { course for practitioners (where participants had to } \\
\text { contribute to the overall strategic plan) and a one-day } \\
\text { course for supervisors. Stages } 3 \text { to } 5 \text { in second article } \\
\text { (below) }\end{array}$} & \multirow{2}{*}{$\begin{array}{l}\text { Positive impact: Large change of culture within the } \\
\text { mental health programme. The estimated } 80 \% \text { of } \\
\text { people initially negative and suspicious about clinical } \\
\text { supervision was now estimated to be only } 15 \% \text { to } \\
30 \% \text {. Considerations: Strategies for sustainability } \\
\text { developed included: continuity of review programme } \\
\text { and leadership team (working group) to oversee } \\
\text { actions and to work with senior management. }\end{array}$} \\
\hline & Level III & Australia & & \\
\hline \multirow[t]{3}{*}{$\begin{array}{l}\text { Lynch and Happell } \\
\text { [34] }\end{array}$} & $\begin{array}{l}\text { Qualitative - } \\
\text { 'exploratory' approach: } \\
\text { document analysis and } \\
\text { interviews }\end{array}$ & Nurses in (mental health) & $\begin{array}{l}\text { Intervention: Examination of the 'process and journey' } \\
\text { of a clinical supervision implementation strategy (Part II) } \\
\text { (face to face) }\end{array}$ & As above \\
\hline & Level III & $\begin{array}{l}\text { Rural: Service examined has } \\
3,000 \text { registered clients } \\
\text { covering } 44,000 \mathrm{~km}^{2}\end{array}$ & \multirow{2}{*}{$\begin{array}{l}\text { Contextual information: Active involvement of staff in } \\
\text { programme design and evaluation (dedicated 'team' } \\
\text { of staff to undertake needs analysis (talking to staff, } \\
\text { assessing workplace culture) and take control of } \\
\text { decisions and implementation. External training for } \\
\text { supervisors and supervisees in supervision; established } \\
\text { a strategic plan; marketed the programme (official } \\
\text { 'launch' of the programme, using a strategic plan to } \\
\text { demonstrate organisational commitment); continual } \\
\text { reflection and gathering of feedback; formal internal } \\
\text { review of programme (demonstrated change, effect, } \\
\text { impact on staff; clear leadership) }\end{array}$} & \\
\hline & & Australia & & \\
\hline \multirow[t]{4}{*}{ English et al. [35] } & $\begin{array}{l}\text { Mixed methods - } \\
\text { 'following a thread' }\end{array}$ & Multi-disciplinary & $\begin{array}{l}\text { Intervention: Secondary analysis of data examining } \\
\text { how the 'inputs' of supervision, feedback and } \\
\text { facilitation affected implementation of best practice } \\
\text { (face to face) }\end{array}$ & $\begin{array}{l}\text { Primary measure: Staff outcomes (qualitative) - skills, } \\
\text { satisfaction, (change in) attitude, leadership }\end{array}$ \\
\hline & \multirow[t]{3}{*}{ Level I } & Rural & \multirow{3}{*}{$\begin{array}{l}\text { Contextual information: External support and } \\
\text { organisational commitment (external supportive } \\
\text { supervision and local management and clear lines of } \\
\text { communication regarding expectations established } \\
\text { prior to programme); attributes of educator (facilitators } \\
\text { were used within intervention hospitals); active } \\
\text { involvement of stakeholders ('health workers must not } \\
\text { only know how to perform a task (for example, } \\
\text { prescribing) but be willing to perform it'); networking } \\
\text { and relationships (team working and integrated } \\
\text { working associated with greater satisfaction) }\end{array}$} & $\begin{array}{l}\text { Secondary measure: (qualitative) service outcomes - } \\
\text { resource allocation, improved clinical systems }\end{array}$ \\
\hline & & \multirow[t]{2}{*}{ Kenya } & & $\begin{array}{l}\text { Positive impact: A multi- faceted intervention strategy } \\
\text { can change provider behaviours and improve the quality } \\
\text { of inpatient care across a range of high mortality, target } \\
\text { diseases. }\end{array}$ \\
\hline & & & & $\begin{array}{l}\text { Considerations: In all settings, health worker } \\
\text { motivation was a challenge }\end{array}$ \\
\hline
\end{tabular}


Table 3 Summary of papers by intervention (Continued)

\begin{tabular}{llll}
\hline Xavier et al. [36] & $\begin{array}{l}\text { Non-experimental - } \\
\text { descriptive pre-and } \\
\text { post-intervention } \\
\text { evaluation }\end{array}$ & Psychologists and social workers & $\begin{array}{l}\text { Intervention: Training, education and supervision. } \\
\text { Clinical supervision and education provided by } \\
\text { videoconference from a tertiary metro teaching } \\
\text { hospital with individual telephone supervision each } \\
\text { month (non-face-to-face: real-time videoconferencing) }\end{array}$ \\
& Level IV & $\begin{array}{l}\text { Contextual information: Externally organised and } \\
\text { supported: site coordinators were available to offer } \\
\text { technical assistance at the majority of the locations. An } \\
\text { administrative assistant was employed to coordinate } \\
\text { the study; needs analysis was undertaken prior to the } \\
\text { event }\end{array}$
\end{tabular}

Primary measures: Staff outcomes - number of participants, self-reported knowledge gains, selfreported confidence in management of particular conditions; satisfaction with the programme

Positive impact: Significant increases in self-reported confidence in the areas covered by the educational

component, for example assessing and treating pain in people with cancer (Po0.01). Self-assessment of overall effectiveness in current management of psychological distress from pre- to post-evaluation increased by $25 \%$ Participants indicated that attending the educational sessions increased their knowledge (mean 1/4 7.3 out of 10). With regard to telephone supervision, most $(80 \%)$ were very or extremely satisfied. The feedback indicated that remote supervision was well received and that participants were keen to continue their involvement. Overall: It is feasible and acceptable to provide clinical supervision and education via videoconference

\section{Papers examining professional support}

\section{Conger and Plager Qualitative -}

[37]

phenomenology

Level II

USA

\begin{tabular}{ll}
\hline Teasley et al. [38] & $\begin{array}{l}\text { Non-experimental - } \\
\text { descriptive pre- and } \\
\text { post-intervention } \\
\text { evaluation }\end{array}$
\end{tabular}

Nurses

Level IV

Rural Kentucky: Community of 5,000, 60 miles from major metropolitan areas

USA
Intervention: Mechanisms promoting connectedness

for masters students in rural areas were identified and

explored (combination: face to face, telephone, email)

Contextual information: Targeted development of

support networks (relationships formed during study,

other professionals in health centre, collaborative

practice, mentoring); targeted development of

relationship with large urban or metro health centres; targeted development of relationship with community; access to technology; avoiding mechanisms that promote disconnectedness (lack of relationships with health centres, poor avenues of communication with other health centres, lack of mentoring)

Intervention: Nurses were requested to participate in meetings that generated and prioritised a list of interventions for implementation to improve perceptions of workload (face to face)

Contextual information: Active involvement of stakeholders in programme design and evaluation; active involvement of staff in change process
Primary measure: Staff outcomes - mechanisms that encouraged connectedness in rural areas

Positive impact: Connectedness enhanced by: development of support networks, relationships with large urban medical centres, availability of electronic communication and connections with the rural community. Graduates who reported a sense of disconnectedness when working in a rural community were less likely to remain in that community

Negative impact: mechanisms that promote disconnectedness such as: lack of relationships with other health centres or poor communication avenues with other health-care centres; lack of mentoring (incidentally felt phone calls not enough)

Primary measure: Staff outcomes - workload perceptions.

Secondary measure: Staff outcomes - satisfaction and retention.

Positive impact: Participant engagement in developing and implementing self-identified work environment

issues led to improved workload, work satisfaction and intent to remain. 
Table 3 Summary of papers by intervention (Continued)

Cameron et al. [39] Qualitative - collective Medical practitioners, community

case study

methodology

Level |

Rural

Alberta, Canada
Intervention: Exploration of community factors that promote physicians to practice and remain in a rural area (face to face)

Contextual information: Active involvement of stakeholders (as evidenced by 'active support' theme); networking and relationships (connection and reciprocity themes)
[40]

Level III

British Colombia, Canada

Level IV Rural
New Mexico, USA

\section{Papers examining training or education}

Arora et al. [41] Non-experimental

descriptive pre- and

post-evaluation

Medical practitioners
Healey-Ogden et al. Qualitative - interviews Nursing
Intervention: Implementation of an 80/20 staffing model whereby staff have $20 \%$ of salaried time off from direct patient care to pursue professional development activities (face to face)

Contextual information: Organisational commitment committee); external support (university, funded by Ministry for Health); accessible and adequate resources with $20 \%$ of time for CPD, training or supervision made available through creation of backfill positions (nurses were paid for their 20\% time off clinical duties and could access funding to pay for travel and courses and so on); leadership (project coordinator was hired between availability of backfill and course availability) (senior management and other partners on steering and utilised); flexibility (timing often mismatched

Primary measure: Staff outcomes - factors that support retention of practitioners (this is also identified as a community outcome)

Positive impact: Four themes emerged. Appreciation connection, active support (for the practitioner and pursuits of the practitioner for example defending health region) and physical and recreational assets were positively related to physician retention. These community factors existed to different degrees but were present in all communities. Reciprocity was a fifth factor that emerged.

Primary measures: Staff outcomes - retention, knowledge, personal growth Secondary measures: Service outcomes - team engagement, quality of care, collaboration

Positive outcomes: 4,000 hours of professiona development and learning activities; positive effect on personal growth and work environment; improved job satisfaction and (unmeasured) intention to remain in job; perceived increase in quality of care; increased collaboration with staff of other hospitals and universities; team development

Considerations: Participants had scheduled professional development time during the summer, but most formal educational opportunities begin in September hence professional development time and the availability of backfill staff did not always match; opportunities sparse in local area implies need for funding for travel and accommodation

Intervention: Use of a 'telehealth clinic' bringing

together metro specialists and rural community based

primary care providers to provide care to hepatitis $C$

sufferers (non-face-to-face: real-time

videoconferencing)

Contextual information: Needs analysis; external

support; financial support (three-year funding grant):

regular feedback and evaluation opportunities; accessible and adequate resources (two-day

orientation to technology and format of sessions);

networking and relationships (development of

'knowledge networks' between practitioners of

different specialities); application of formal learning

strategy (learning loops)
Primary measures: Service outcomes (from patient level) - efficiency, access and quality/completeness

Secondary measures: Quality and completeness of health information and services received by clients

Positive impact: Uniform agreement by participants benefit to the practice and patients, expanded access to specialists, and the provider's professional enhancement; significant increase in competency sustained for $>12$ months; competent to educate others; perceived improvements in patient safety and quality of care 
Table 3 Summary of papers by intervention (Continued)

\begin{tabular}{|c|c|c|c|c|}
\hline \multirow[t]{3}{*}{$\begin{array}{l}\text { Bennett-Levy et al. } \\
{[42]}\end{array}$} & $\begin{array}{l}\text { Experimental - } \\
\text { randomised controlled } \\
\text { trial }\end{array}$ & $\begin{array}{l}\text { Multi-disciplinary (psychologists, } \\
\text { social workers, nurses, counsellors, } \\
\text { medical practitioners) }\end{array}$ & $\begin{array}{l}\text { Intervention: Online training programme for rural and } \\
\text { remote mental health practitioners in cognitive } \\
\text { behavioural therapy (CBT) (non-face-to-face: internet, } \\
\text { video clips) }\end{array}$ & $\begin{array}{l}\text { Primary measures: Staff outcomes - CBT knowledge, } \\
\text { skills, confidence, utilisation and satisfaction with } \\
\text { programme }\end{array}$ \\
\hline & \multirow[t]{2}{*}{ Level ॥ } & Urban, regional, rural & \multirow{2}{*}{$\begin{array}{l}\text { Contextual information: External support; accessible } \\
\text { and adequate resources (discounted access to online } \\
\text { learning programme provided); networking and } \\
\text { relationships (15-min support sessions provided by } \\
\text { experienced psychologist after each online learning } \\
\text { module completed) }\end{array}$} & \multirow[b]{2}{*}{$\begin{array}{l}\text { Positive impact: Participants in both groups improved } \\
\text { their performance scores from pre-program to post- } \\
\text { program and follow-up; supported training group was } \\
\text { more likely to finish or very nearly finish }(96 \%) \text { than } \\
\text { the independent group }(76 \%)(c 2=3.93, d f=1, P \\
<.05) ; \text { program characteristics, including the program } \\
\text { design and content, proved highly acceptable; value } \\
\text { of the } 15 \text {-min support sessions was almost unani- } \\
\text { mously endorsed by the supported training group }\end{array}$} \\
\hline & & Australia & & \\
\hline \multirow[t]{3}{*}{ Blattner et al. [43] } & $\begin{array}{l}\text { Qualitative - thematic } \\
\text { analysis of interviews }\end{array}$ & Nurses and medical practitioners & $\begin{array}{l}\text { Intervention: Staff at a rural hospital were trained in } \\
\text { using a newly installed point of care test analyser (face } \\
\text { to face) }\end{array}$ & $\begin{array}{l}\text { Primary measures: Staff outcomes - change in practice } \\
\text { behaviour, job satisfaction, process facilitators and } \\
\text { barriers Secondary measures: Service outcomes - } \\
\text { sustainability of intervention }\end{array}$ \\
\hline & \multirow[t]{2}{*}{ Level III } & Remote & \multirow[t]{2}{*}{$\begin{array}{l}\text { Contextual information: Access to training, skills, } \\
\text { knowledge for the intervention (including refresher } \\
\text { courses in interpreting tests); accessible and adequate } \\
\text { resources (point of care test analyser located on ward) }\end{array}$} & $\begin{array}{l}\text { Positive impact: Training and use of point of care } \\
\text { testing increased diagnostic certainty and improved } \\
\text { confidence in clinical decision-making; transfer deci- } \\
\text { sions could be made earlier than they otherwise } \\
\text { would have been and often treatment could begin im- } \\
\text { mediately; reduced need for inter-hospital transfers } \\
\text { and increased discharge rate; higher standards of prac- } \\
\text { tice; access to continuing professional education (CPE) }\end{array}$ \\
\hline & & New Zealand & & $\begin{array}{l}\text { Negative outcomes: Workload increase - managing } \\
\text { patients who would previously have been transferred } \\
\text { and who now require more care; can be time- } \\
\text { consuming; over-testing may become a problem }\end{array}$ \\
\hline \multirow[t]{4}{*}{ Brambila et al. [44] } & \multirow{2}{*}{$\begin{array}{l}\text { Quasi-experimental - } \\
\text { pre- and post- } \\
\text { intervention and control } \\
\text { groups }\end{array}$} & \multirow[t]{2}{*}{ Health practitioners $(n=40)$} & \multirow{2}{*}{$\begin{array}{l}\text { Intervention: Train the trainer: snowballing of a training } \\
\text { intervention where two practitioners from each health } \\
\text { district }(n=20 \times 2 \text { trainers) undertook training in tools } \\
\text { to improve service quality. They then each trained } \\
\text { approximately six trainees per health district in the } \\
\text { programme (face to face) }\end{array}$} & $\begin{array}{l}\text { Primary measures: Service outcomes (from patient } \\
\text { level) - efficiency, access, quality and completeness }\end{array}$ \\
\hline & & & & $\begin{array}{l}\text { Secondary measures: Service and patient outcomes - } \\
\text { quality and completeness of health information and } \\
\text { services received by clients }\end{array}$ \\
\hline & \multirow[t]{2}{*}{ Level III-3 } & $\begin{array}{l}\text { Rural: Approximate population } \\
\text { served 580,000 individuals }\end{array}$ & \multirow{2}{*}{$\begin{array}{l}\text { Contextual information: External support, coordination } \\
\text { and programme; structure and content of programme; } \\
\text { train trainers how to use job tools to improve service } \\
\text { quality; train trainers how to train health-care practi- } \\
\text { tioners; motivational and attitudinal change elements } \\
\text { built into curriculum; needs assessment (content of } \\
\text { programme in response to problem areas); appropriate } \\
\text { skills and knowledge }\end{array}$} & $\begin{array}{l}\text { Positive impact: Access to services increased } \\
\text { significantly }\end{array}$ \\
\hline & & Guatemala & & $\begin{array}{l}\text { No impact: No reduction in client waiting times or } \\
\text { total time spent by clients at facilities }\end{array}$ \\
\hline
\end{tabular}


Table 3 Summary of papers by intervention (Continued)

\begin{tabular}{|c|c|c|c|c|}
\hline \multirow[t]{3}{*}{ Buckley et al. [45] } & $\begin{array}{l}\text { Non-experimental - } \\
\text { descriptive post- } \\
\text { intervention evaluation }\end{array}$ & Nurses & $\begin{array}{l}\text { Intervention: Digital photographs were used to } \\
\text { develop treatment plans and assess competency of } \\
\text { non-specialist nurses in wound management utilising } \\
\text { specialist support (non-face-to-face: telephone, email } \\
\text { and digital photography) }\end{array}$ & $\begin{array}{l}\text { Primary measures: Service outcomes - agreement on } \\
\text { wound assessment and wound management plan } \\
\text { between specialist and non-specialist nurse }\end{array}$ \\
\hline & \multirow[t]{2}{*}{ Level IV } & Rural & \multirow{2}{*}{$\begin{array}{l}\text { Contextual information: Access to technology } \\
\text { (computer, internet, email, digital cameras, IT } \\
\text { programmes); correct use of technology, ability to use } \\
\text { technology (issues identified around ability to take the } \\
\text { 'right' picture); information privacy (permission to } \\
\text { transmit patient information via email); appropriate use } \\
\text { and combination of technology to achieve desired } \\
\text { outcomes (intervention needed both verbal and } \\
\text { pictorial reporting to improve accuracy of reporting) }\end{array}$} & $\begin{array}{l}\text { Positive impact: Agreement on more basic assessment } \\
\text { parameters. }\end{array}$ \\
\hline & & USA & & $\begin{array}{l}\text { Less impact: On average there was poor agreement } \\
\text { on more complex parameters. Verbal reports often } \\
\text { missed vital signs leading to poor agreement between } \\
\text { the specialist and non-specialists. }\end{array}$ \\
\hline \multirow[t]{4}{*}{ Church et al. [46] } & \multirow{2}{*}{$\begin{array}{l}\text { Mixed methods - pre-, } \\
\text { during and post- } \\
\text { intervention question- } \\
\text { naire and focus groups }\end{array}$} & \multirow[t]{2}{*}{ Multi-disciplinary } & \multirow{2}{*}{$\begin{array}{l}\text { Intervention: Interprofessional education programme } \\
\text { in mental health for practitioners in six rural } \\
\text { communities (combination: face to face, } \\
\text { videoconferencing) }\end{array}$} & $\begin{array}{l}\text { Primary measures: Staff outcomes - satisfaction, } \\
\text { knowledge, skills, confidence }\end{array}$ \\
\hline & & & & $\begin{array}{l}\text { Considerations: Vision is necessary for accurate } \\
\text { diagnosis, potentially not just of the wound but of the } \\
\text { home environment also }\end{array}$ \\
\hline & \multirow[t]{2}{*}{ Level IV } & Rural & \multirow{2}{*}{$\begin{array}{l}\text { Contextual information: External support (programme } \\
\text { run and supported by researchers); networking and } \\
\text { relationships (professionals from different systems } \\
\text { brought together, structure of the programme - small } \\
\text { groups, interactive, case-based learning) }\end{array}$} & \multirow[b]{2}{*}{$\begin{array}{l}\text { Positive impact: Significant increase in confidence for } \\
\text { seven of the eight mental health interventions and } \\
\text { four of the six mental health issues that had been } \\
\text { taught in the programme; more reflective mental } \\
\text { health practice, more aware of mental health issues; } \\
\text { integrating new knowledge and skills into their work; } \\
\text { interprofessional referrals, interagency linkages and } \\
\text { collaboration increased }\end{array}$} \\
\hline & & $\begin{array}{l}\text { Rural Newfoundland and } \\
\text { Labrador, Canada }\end{array}$ & & \\
\hline \multirow[t]{3}{*}{$\begin{array}{l}\text { Cunningham et al. } \\
\text { [47] }\end{array}$} & $\begin{array}{l}\text { Qualitative - focus } \\
\text { groups }\end{array}$ & Administrative and clerical staff & $\begin{array}{l}\text { Intervention: Mechanisms contributing to effective } \\
\text { protected learning time were identified (face to face) }\end{array}$ & $\begin{array}{l}\text { Primary measures: Staff outcomes - satisfaction with, } \\
\text { benefits of, advantages and disadvantages of PLT }\end{array}$ \\
\hline & \multirow[t]{2}{*}{ Level III } & Rural & \multirow{2}{*}{$\begin{array}{l}\text { Contextual information: Organisational commitment; } \\
\text { structured learning outcomes; structure of the } \\
\text { programme (spending time with other teams and } \\
\text { services, spending time with immediate colleagues, } \\
\text { centrally organised events) }\end{array}$} & \multirow{2}{*}{$\begin{array}{l}\text { Positive impact: Useful to do with other teams and } \\
\text { team members especially team-building activities Con- } \\
\text { siderations: Increased workload the day after. Needs to } \\
\text { include quality educational experiences. May be im- } \\
\text { proved using a learning needs assessment }\end{array}$} \\
\hline & & Scotland, UK & & \\
\hline
\end{tabular}


Table 3 Summary of papers by intervention (Continued)

\begin{tabular}{|c|c|c|c|c|}
\hline \multirow[t]{3}{*}{$\begin{array}{l}\text { Doorenbos et al. } \\
\text { [14] }\end{array}$} & $\begin{array}{l}\text { Non-experimental - } \\
\text { descriptive post- } \\
\text { evaluation }\end{array}$ & Multi-disciplinary & $\begin{array}{l}\text { Intervention: A series of cancer education sessions } \\
\text { were delivered using telehealth technology to rural } \\
\text { health-care providers (non-face-to-face: real-time } \\
\text { videoconferencing) }\end{array}$ & $\begin{array}{l}\text { Primary measures: Staff outcomes - satisfaction } \\
\text { (content and mode), attendance rates }\end{array}$ \\
\hline & \multirow[t]{2}{*}{ Level IV } & Rural & \multirow[b]{2}{*}{$\begin{array}{l}\text { Contextual information: Active involvement of } \\
\text { stakeholders (participants worked with university and } \\
\text { clinical experts to develop cancer programme; } \\
\text { participating rural health-care providers were also en- } \\
\text { gaged in selecting topics and identifying convenient } \\
\text { and feasible dates and times for the videoconference } \\
\text { presentations); needs analysis; marketing the } \\
\text { programme (the series was publicised and scheduled } \\
\text { well in advance to allow providers to plan attendance } \\
\text { at the presentations most relevant to them); accessible } \\
\text { and adequate resources; external support (university } \\
\text { technical staff hosted each presentation and were con- } \\
\text { tinually available for troubleshooting technological } \\
\text { problems) }\end{array}$} & \multirow{2}{*}{$\begin{array}{l}\text { Positive impact: Overall satisfaction with telehealth as a } \\
\text { mode of delivery; educational session information } \\
\text { rated highly; high attendance rates; accessing CPE } \\
\text { became a reality for rural health-care providers }\end{array}$} \\
\hline & & $\begin{array}{l}\text { Washington State, rural } \\
\text { Alaska, USA }\end{array}$ & & \\
\hline \multirow[t]{3}{*}{ D'Souza [48] } & $\begin{array}{l}\text { Non experimental - } \\
\text { cross-sectional ques- } \\
\text { tionnaire design post- } \\
\text { intervention }\end{array}$ & $\begin{array}{l}\text { Mental health practitioners } \\
\text { and medical practitioners } \\
\text { (general practitioners (GPs)) }\end{array}$ & $\begin{array}{l}\text { Intervention: Delivery of educational and clinical } \\
\text { modules for mental health via telemedicine and } \\
\text { videoconferencing facilities (non-face-to-face: real-time } \\
\text { videoconferencing) }\end{array}$ & $\begin{array}{l}\text { Primary measures: Staff outcomes - satisfaction with } \\
\text { the service and associated outcomes; feelings of } \\
\text { isolation, fulfilling of academic needs, relevance to } \\
\text { professional development, effect on self-assessed com- } \\
\text { petence with mental health clients }\end{array}$ \\
\hline & \multirow[t]{2}{*}{ Level IV } & Rural & \multirow{2}{*}{$\begin{array}{l}\text { Contextual information: Access to technology; timing } \\
\text { of delivery (during team meeting time); mode of } \\
\text { delivery (videoconferencing); structure and content of } \\
\text { programme (lecture notes delivered prior to } \\
\text { videoconferencing, 60-minute CPD blocks plus inter- } \\
\text { active discussion time) }\end{array}$} & \multirow{2}{*}{$\begin{array}{l}\text { Positive impact: High satisfaction scores with the } \\
\text { service fulfilling their professional and academic needs. } \\
\text { The service helped improve confidence and } \\
\text { competence in managing mental illness }\end{array}$} \\
\hline & & Australia & & \\
\hline \multirow[t]{2}{*}{ Ellis and Philip [49] } & $\begin{array}{l}\text { Mixed methods - pre- } \\
\text { and post-questionnaire } \\
\text { and interviews }\end{array}$ & Multi-disciplinary & $\begin{array}{l}\text { Intervention: Development, delivery and evaluation of } \\
\text { a short course in managing mental health } \\
\text { emergencies at rural and remote health sites (face to } \\
\text { face) }\end{array}$ & $\begin{array}{l}\text { Primary measures: Staff outcomes - skills, satisfaction, } \\
\text { attitude }\end{array}$ \\
\hline & Level IV & $\begin{array}{l}\text { Rural and remote towns in } \\
\text { South Australia, Northern Territory, } \\
\text { Queensland and Western Australia }\end{array}$ & $\begin{array}{l}\text { Contextual information: External support (conducted } \\
\text { by Australian rural nurses and midwives using grant } \\
\text { from Department of Health and Ageing); adequate } \\
\text { and accessible resources (workbook provided to } \\
\text { participants; course delivered in rural and remote sites; } \\
\text { mode of delivery - face to face) }\end{array}$ & $\begin{array}{l}\text { Positive impact: Significant improvement between pre } \\
\text { and post mental health assessment skills (unmatched } \\
\text { comparison); changed attitudes towards mental } \\
\text { health; improved communication ability when dealing } \\
\text { with mental health clients }\end{array}$ \\
\hline
\end{tabular}

tionnaire design post- (general practitioners (GPs)

Rura 
Table 3 Summary of papers by intervention (Continued)

Glazebrook et al. Non-experimental - Medical practitioners

[50]

$$
\text { pre- and post-test }
$$

evaluation

Level IV

Small rural hospitals

Australia

\begin{tabular}{lll}
\hline $\begin{array}{l}\text { Gorsche and } \\
\text { Woloschuk [51] }\end{array}$ & $\begin{array}{l}\text { Quasi-experimental - } \\
\text { longitudinal, matched, } \\
\text { case-control study }\end{array}$ & Medical practitioners \\
& Level III-2 & $\begin{array}{l}\text { Rural: Any Alberta community } \\
\text { more than } 50 \mathrm{~km} \text { from a majo }\end{array}$
\end{tabular}

metropolitan centre

Canada

\begin{tabular}{ll}
\hline Haythornthwaite & $\begin{array}{l}\text { Non-experimental - } \\
\text { descriptive pre- and } \\
\text { [52] }\end{array}$ \\
& post-intervention
\end{tabular}

Mental health practitioners

evaluation

Level IV

Rural and remote

Western Australia

Aboriginal health workers

\begin{tabular}{ll}
\hline King et al. [53] & Qualitative - critical \\
ethnographic post-
\end{tabular}

intervention

Level II $\quad$ Rural and remote

South Australia
Intervention: Outreach ultrasound education

workshops held in rural locations - specialist doctors

from metro areas delivered workshops with local

sonographers (face to face)

Contextual information: External support and

organisation; local support (local experts utilised)

funding and travel for outreach experts; structure and

content of programme (face-to-face: hands-on

workshops)

Intervention: Training programmes run within an

'enrichment programme' for rural and remote medics (mode not specified)

Contextual information: External support (initiative of the Alberta government); accessible and adequate resources (fully supported to undertake training of choice - for example preceptors were compensated and locums arranged)
Intervention: A post-graduate university course undertaken by Aboriginal health workers (developed for nurses and allied health practitioners) to qualify them as diabetes educators

Contextual information: Reflection, feedback, evaluating outcome of the course; the course has to be relevant and academically targeted appropriate to the participant
Primary measures: Staff outcomes - pre- and postworkshop knowledge tests (unvalidated)

Secondary: Self-rated levels of knowledge, confidence and expertise in ultrasound

Positive impact: Significant improvement in knowledge and self-reported confidence with ultrasound by

medical practitioners

Primary measures: staff outcomes - goal attainment and retention.

Positive impact: $97 \%$ of participants achieved training or learning goals; all participants were using their new or upgraded skills at 5 years; after 5 years, 100\% in the matched enrichment group remained in rural practice compared with $71 \%$ physicians who did not partake in the EP (RR $=1.31$. confidence interval: 1.06 to 1.62 $P<0.05)$.

Only paper to demonstrate a statistical link between supportive context, skill acquisition and retention of rural practitioners.

Primary measures: Staff outcomes - number of participants, knowledge in relation to the training presented over 12 weeks ('Rural Links' programme). Included fort reading material on topics covered and workbooks for use in-session (non-face-to-face: multi-site real-time

Contextual information: Access to technology: resources: workbooks and session exercises; assume externally organised

training modality, participant satisfaction

Positive impact: Varied significant improvements in knowledge gains for particular teaching modules (although not consistent gains for all modules); compared with metropolitan participants, who received face-to-face training, rural participants showed similar levels of improvement in learning for most areas; high levels of participant satisfaction with videoconferencing delivery and programme content

Primary measures: Staff outcomes - perceptions of the course, development as a health practitioner,

relevance of the course to self and clients, learning outcomes

Positive impact: Undertaking a post-graduate diabetes education course can improve confidence and competence in Aboriginal health workers. Course helped the Aboriginal health workers become more confident and competent as health professionals and empowered to learn and impart new knowledge as a practitioner 
Table 3 Summary of papers by intervention (Continued)

\begin{tabular}{|c|c|c|c|c|}
\hline \multirow[t]{4}{*}{ Kelley et al. [54] } & $\begin{array}{l}\text { Non-experimental - } \\
\text { cross-sectional survey } \\
\text { design }\end{array}$ & Palliative carers & $\begin{array}{l}\text { Intervention: Information regarding how a training } \\
\text { programme was developed, planned and delivered in } \\
\text { collaboration with local community partners (face to } \\
\text { face) }\end{array}$ & $\begin{array}{l}\text { Primary measures: Staff outcomes - self-reported } \\
\text { knowledge and skills of practitioners. Service outcomes } \\
\text { - sustainability of the programme, development of } \\
\text { palliative care programmes in other agencies or the } \\
\text { community }\end{array}$ \\
\hline & \multirow[t]{3}{*}{ Level IV } & $\begin{array}{l}\text { Rural: 'Towns and municipalities } \\
\text { less than } 10,000 \text { population and } \\
\text { located outside the commuting } \\
\text { zone of urban centres larger than } \\
10,000 \text { population.' Remote: 'isolated } \\
\text { community with limited resources, } \\
80 \mathrm{~km} \text { distance or four or more } \\
\text { hours travel from a major urban } \\
\text { centre of }>50,000 \text { population' }\end{array}$ & \multirow[t]{3}{*}{$\begin{array}{l}\text { Contextual information: Course content was locally } \\
\text { relevant; networking opportunities; train-the-trainer ap- } \\
\text { proach, emphasis within course material on training } \\
\text { participants to translate their knowledge gains to co- } \\
\text { workers }\end{array}$} & $\begin{array}{l}\text { Positive impact: Increase in self-reported knowledge, } \\
\text { confidence in practice and skills. Sustainable via partici- } \\
\text { pants imparting learnt knowledge via mentoring and } \\
\text { workshops to co-workers. May increase number of } \\
\text { palliative care programmes. }\end{array}$ \\
\hline & & \multirow[t]{2}{*}{ Canada } & & $\begin{array}{l}\text { Considerations: Networking and learning about } \\
\text { supporting resources were identified as the most } \\
\text { important elements of the programme; able to } \\
\text { collaborate more as a group to improve services and } \\
\text { act as a common voice. Indicated they shared } \\
\text { information with other staff via mentoring, meetings, } \\
\text { case conferences, formal in-service sessions, formal } \\
\text { workshops. }\end{array}$ \\
\hline & & & & $\begin{array}{l}\text { Ideal learning: Off site in nearby town, small groups, } \\
\text { interactive }\end{array}$ \\
\hline \multirow[t]{3}{*}{ Koczwara et al. [55] } & $\begin{array}{l}\text { Non-experimental - } \\
\text { descriptive planning } \\
\text { phase and post- } \\
\text { evaluation }\end{array}$ & Multi-disciplinary & $\begin{array}{l}\text { Intervention: Development, implementation and } \\
\text { evaluation of an online educational programme } \\
\text { (oncology) for rural health practitioners }\end{array}$ & $\begin{array}{l}\text { Primary measures: Staff outcomes - change in } \\
\text { practice, satisfaction with programme, users } \\
\text { (attendance) }\end{array}$ \\
\hline & \multirow[t]{2}{*}{ Level IV } & Rural and remote & \multirow[b]{2}{*}{$\begin{array}{l}\text { Contextual information: Needs analysis (survey and } \\
\text { focus groups conducted with rural practitioners); } \\
\text { regular feedback and evaluation opportunities; } \\
\text { marketing of the programme (programme launch at } \\
\text { national conference, online advertising to target } \\
\text { audiences); accessible and adequate resources; } \\
\text { networking and relationships; employ specific learning } \\
\text { approach; skills to deliver the intervention (facilitator } \\
\text { employed and trained in online environment and } \\
\text { subject matter) }\end{array}$} & \multirow{2}{*}{$\begin{array}{l}\text { Positive impact: High attendance and completion } \\
\text { rates; perceived change in practice as a result of } \\
\text { completion of learning programme; learning needs } \\
\text { met and achievement of specific learning goals; high } \\
\text { satisfaction with online multimedia }\end{array}$} \\
\hline & & Australia & & \\
\hline
\end{tabular}


Table 3 Summary of papers by intervention (Continued)

\begin{tabular}{|c|c|c|c|c|}
\hline \multirow[t]{4}{*}{ Newman et al. [56] } & \multirow{2}{*}{$\begin{array}{l}\text { Non-experimental - } \\
\text { cross-sectional survey } \\
\text { post-intervention }\end{array}$} & \multirow[t]{2}{*}{ Multi-disciplinary } & \multirow{2}{*}{$\begin{array}{l}\text { Intervention: Use of videoconference facility in } \\
\text { different urban and rural settings to deliver a one-off } \\
\text { education conference }\end{array}$} & $\begin{array}{l}\text { Primary measures: Staff outcomes - knowledge, } \\
\text { socialisation, information exchange, ease of use }\end{array}$ \\
\hline & & & & $\begin{array}{l}\text { Secondary measures: Numbers of participants, } \\
\text { geographic location }\end{array}$ \\
\hline & \multirow[t]{2}{*}{ Level IV } & Urban, rural and remote & \multirow{2}{*}{$\begin{array}{l}\text { Contextual information: External support and } \\
\text { organisation (technical preparation of } \\
\text { videoconferencing was by the conferencing and } \\
\text { media staff from the lead hospital or health service in } \\
\text { liaison with staff and departments from other services; } \\
\text { 'site facilitators' utilised at each site); adequate } \\
\text { preparation (speakers provided with guidelines on } \\
\text { etiquette and teaching methods); teaching rehearsals } \\
\text { prior to event }\end{array}$} & $\begin{array}{l}\text { Positive impact: Useful for learning and were able to } \\
\text { contribute or be part of a learning community }\end{array}$ \\
\hline & & Australia & & $\begin{array}{l}\text { Less impact: Mostly a passive experience. Not overly } \\
\text { easy to use }\end{array}$ \\
\hline \multirow[t]{4}{*}{ Schoo et al. [57] } & \multirow{2}{*}{$\begin{array}{l}\text { Mixed methods - } \\
\text { action research } \\
\text { (questionnaire and } \\
\text { interviews) }\end{array}$} & \multirow[t]{2}{*}{ Physiotherapists } & \multirow{2}{*}{$\begin{array}{l}\text { Intervention: Continuing education programme } \\
\text { developed, implemented and evaluated by local } \\
\text { physiotherapy practitioners with researchers from a } \\
\text { university (face to face) }\end{array}$} & $\begin{array}{l}\text { Primary measures: Staff outcomes - relevance, } \\
\text { attendance of programme }\end{array}$ \\
\hline & & & & $\begin{array}{l}\text { Secondary measures: Staff outcomes - perceived effect } \\
\text { on clinical practice }\end{array}$ \\
\hline & \multirow[t]{2}{*}{ Level III (Daly) } & $\begin{array}{l}\text { Regional and rural: 'Accessible and } \\
\text { moderately accessible' on the } \\
\text { Accessibility/Remoteness Index }\end{array}$ & \multirow{2}{*}{$\begin{array}{l}\text { Contextual information: Location of programme } \\
\text { (locally delivered); teacher attributes (highly qualified); } \\
\text { needs analysis prior to programme development; } \\
\text { active involvement of stakeholders in programme } \\
\text { development and evaluation (identification of targets } \\
\text { and measures for success prior to intervention, active } \\
\text { participant engagement with institutional facilitation); } \\
\text { external organisation, input and facilitation (needs } \\
\text { assessment, development of programme, evaluation } \\
\text { tools) }\end{array}$} & \multirow{2}{*}{$\begin{array}{l}\text { Positive impact: All targets were reached. Attendance } \\
\text { - more than half ( } 57.2 \% \text { ) of physiotherapists in the } \\
\text { region attended a minimum of four sessions and } \\
68.6 \% \text { attended at least one 'on-site' workshop. More } \\
\text { than two-thirds of the physiotherapists (68.6\%) knew } \\
\text { of others who attended at least one of the continuing } \\
\text { education (CE) functions of the } 2004 / 5 \text { programme } \\
\text { and } 45.7 \% \text { of these physiotherapists received useful } \\
\text { information from others who attended. Interactive CE } \\
\text { programme had a positive influence on perceived } \\
\text { clinical skills }\end{array}$} \\
\hline & & Australia (ARIA) & & \\
\hline \multirow[t]{3}{*}{ White et al. [58] } & $\begin{array}{l}\text { Non-experimental - } \\
\text { cross-sectional survey } \\
\text { post-intervention }\end{array}$ & Medical practitioners (GPs) & $\begin{array}{l}\text { Intervention: Government-run CME workshops (face to } \\
\text { face) }\end{array}$ & $\begin{array}{l}\text { Primary measures: Staff outcomes - professional } \\
\text { isolation, confidence, commitment to remain in rural } \\
\text { practise (retention) }\end{array}$ \\
\hline & \multirow[t]{2}{*}{ Level IV } & $\begin{array}{l}\text { Rural: Rural Remote and } \\
\text { Metropolitan Areas (RRMA) } \\
\text { classification four to seven locations }\end{array}$ & \multirow{2}{*}{$\begin{array}{l}\text { Contextual information: Needs analysis; clinician-led } \\
\text { content; funding (government department funded } \\
\text { travel and accommodation); time relief (locum support } \\
\text { or locum rebates available for more remote GPs) }\end{array}$} & \multirow{2}{*}{$\begin{array}{l}\text { Positive impact: Access to CME contributes to } \\
\text { confidence in practicing in remote and rural areas; } \\
\text { CME strongly alleviates professional isolation; less likely } \\
\text { to remain in practice without access to CME }\end{array}$} \\
\hline & & Australia & & \\
\hline
\end{tabular}
external organisation, input and facilitation (needs 
Table 3 Summary of papers by intervention (Continued)

Wright et al. [59] Non-experimental - Medical practitioners descriptive pre- and post-evaluation

Level IV

Regional and rural: RRMA two to five Australia
Intervention: Evaluation of an educational support

programme for international practitioners practicing in

rural areas (combination: simulated face-to-face consu-

tations, workshops, weekly meetings, interactive web-

based learning modules)

Contextual information: Needs analysis (via a pre-

programme learning needs analysis); regular feedback and evaluation opportunities (post workshop and session evaluations and post programme evaluation); accessible and adequate resources

Primary measures: Staff outcomes - clinical practice and competency, retention (at three months post-

intervention): satisfaction with the programme

Positive impact: Needs assessment enabled participants to articulate specific skills and knowledge that would assist them to work more effectively in their current clinical contexts; statistically significant and positive changes were identified post-intervention for (i) technical skills appropriate to current practice; (ii) willingness and effectiveness when teaching or training colleagues and (iii) communication with carers and ment of a learning community in Gippsland

\section{Papers examining mentoring}

Butcher [60]

Non-experimental
descriptive pre-post-

evaluation

Level IV
Nurses and dietitians

Remote: Population of 902,195

spread across 147,042 square miles:

population density of 6.2 persons

per square mile

USA
Intervention: Mentoring to upskill or train to become

certified diabetes educators or simply to improve knowledge of diabetes (combination: face to face, telephone, email)

Contextual information: Needs assessment (learning needs of all enrolled in programme were assessed an matched to course materials and a mentor); external support and coordination (central coordinator

designated to programme); resources (lending library

for study, mentoring manual for mentors and

mentees); structure and content of the programme:

mentoring was face to face, telephone and email;

observation of mentor in diabetes management also encouraging; combination of mentoring programme structure, content and delivery modes (email, face to face, resources)
Primary measures: Service outcomes - access to

quality diabetes services; staff outcomes satisfaction with programme

Positive impact: 30\% of enrolled nurses and dietitians gained certification. Number of educators increased $47 \%$ (but unsure if directly related to intervention) 
Table 3 Summary of papers by intervention (Continued)

\begin{tabular}{|c|c|c|c|c|}
\hline \multirow[t]{3}{*}{ Gibb et al. [61] } & $\begin{array}{l}\text { Qualitative - focus } \\
\text { groups held before } \\
\text { and after an action } \\
\text { research intervention }\end{array}$ & Nurses & $\begin{array}{l}\text { Intervention: Research officer worked with staff to } \\
\text { develop a definition of mentoring, the results of which } \\
\text { were converted into questionnaires by the research } \\
\text { team eventually becoming a set of guidelines of } \\
\text { desired qualities for mentors and mentees and an } \\
\text { evaluation tool for monitoring the mentoring } \\
\text { relationship (mode: n/a) }\end{array}$ & $\begin{array}{l}\text { Primary measures: Staff outcomes - understanding of } \\
\text { mentoring, key qualities in mentors and mentees, } \\
\text { success of mentoring strategy }\end{array}$ \\
\hline & \multirow[t]{2}{*}{ Level III } & Small rural hospitals & \multirow[b]{2}{*}{$\begin{array}{l}\text { Contextual information: Needs analysis (staff } \\
\text { perception of mentoring needs); external support } \\
\text { (facilitation of action research by university); active } \\
\text { involvement of stakeholders in programme design and } \\
\text { evaluation (the act of coming to an understanding } \\
\text { and a working definition of mentoring in context; } \\
\text { action research enabled greater understanding of role } \\
\text { of mentoring, which in turn allowed for effective } \\
\text { mentoring relationships to develop); conversion of } \\
\text { discussion into a questionnaire for evaluation and into } \\
\text { a guideline document for mentoring }\end{array}$} & Positive impact: More structured mentoring practice \\
\hline & & Australia & & $\begin{array}{l}\text { Considerations: Qualities of a good mentor were } \\
\text { identified, action research enabled greater } \\
\text { understanding of role of mentoring which in turn } \\
\text { allowed for effective mentoring relationships to } \\
\text { develop. Link identified between mentoring and } \\
\text { development of clinical competence. Key to successful } \\
\text { mentoring was management support }\end{array}$ \\
\hline \multicolumn{5}{|c|}{ Papers examining a combination of support interventions } \\
\hline \multirow[t]{3}{*}{ Dalton et al. [62] } & $\begin{array}{l}\text { Mixed methods - pre- } \\
\text { and post-intervention } \\
\text { evaluation }\end{array}$ & Pharmacists & $\begin{array}{l}\text { Intervention: Education, training and mentoring. } \\
\text { Online preceptor education programme with } \\
\text { interactive learning modules and online interactive } \\
\text { mentoring via discussion groups (non-face-to-face: } \\
\text { real-time videoconferencing, telephone, email) }\end{array}$ & $\begin{array}{l}\text { Primary measures: Staff outcomes - assessment of the } \\
\text { programme's implementation, design and delivery } \\
\text { from the preceptors' perspective }\end{array}$ \\
\hline & \multirow[t]{2}{*}{ Level IV } & $\begin{array}{l}\text { Rural: Accessibility/Remoteness } \\
\text { Index of Australia (ARIA) } \\
\text { categories } 1 \text { to } 6 .\end{array}$ & \multirow[t]{2}{*}{$\begin{array}{l}\text { Contextual information: Correct use of technology and } \\
\text { ability to use technology; willingness of participant to } \\
\text { undertake self-directed learning }\end{array}$} & $\begin{array}{l}\text { Positive impact: Interactive elements of the online } \\
\text { programme, such as reflective exercises, were useful } \\
\text { for learning }\end{array}$ \\
\hline & & Australia & & $\begin{array}{l}\text { Considerations: Some IT issues. Introductory video } \\
\text { would be useful for programme but weekend course } \\
\text { or videoconferencing is a better mode of delivery. } \\
\text { Telephone helpline would be useful Limitations: } \\
\text { Presumed pharmacists were good self-directed } \\
\text { learners and had adequate IT skills }\end{array}$ \\
\hline \multirow[t]{3}{*}{ Gardner et al. [63] } & $\begin{array}{l}\text { Non-experimental - } \\
\text { descriptive post- } \\
\text { evaluation }\end{array}$ & Nurses & $\begin{array}{l}\text { Intervention: Professional support, training and } \\
\text { education; supporting nurses in rural areas to } \\
\text { understand and conduct research (combination: face } \\
\text { to face, videoconferencing, telephone, email) }\end{array}$ & $\begin{array}{l}\text { Primary measure: Staff outcomes - orientation to } \\
\text { research }\end{array}$ \\
\hline & \multirow[t]{2}{*}{ Level IV } & Rural and remote & \multirow[b]{2}{*}{$\begin{array}{l}\text { Contextual information: External support; accessible } \\
\text { and adequate resources (all participants had access to } \\
\text { necessary resources; textbooks and resource packages } \\
\text { were provided as well as access to computers during } \\
\text { the workshops); active involvement of participants } \\
\text { (content of programme was responsive to the needs } \\
\text { of the nurses at the rural and remote sites); } \\
\text { networking and relationships (mentorship and } \\
\text { collaboration encouraged) }\end{array}$} & \multirow{2}{*}{$\begin{array}{l}\text { No impact: the survey results do not demonstrate any } \\
\text { major changes over time in perceived knowledge of } \\
\text { research, research orientation or perceptions of barriers } \\
\text { and supports to research. Despite the same structured } \\
\text { educational intervention being delivered at two rural } \\
\text { sites, clinical nurses at only one site completed the } \\
\text { research proposals within the study timeframe }\end{array}$} \\
\hline & & Australia & & \\
\hline
\end{tabular}




\section{Table 3 Summary of papers by intervention (Continued)}

\begin{tabular}{|c|c|c|c|c|}
\hline \multirow[t]{3}{*}{ Hoon et al. [64] } & $\begin{array}{l}\text { Mixed methods - } \\
\text { before and after } \\
\text { design, action research }\end{array}$ & Nurses and medical practitioners & $\begin{array}{l}\text { Intervention: Training, education and mentoring; } \\
\text { information on how a training programme was } \\
\text { developed: planned and delivered in collaboration } \\
\text { with local community partners (face to face) }\end{array}$ & $\begin{array}{l}\text { Primary measures: Staff outcomes - knowledge and } \\
\text { skills in the delivery of chemotherapy and cancer care } \\
\text { education. Service outcomes - connection between } \\
\text { local rural health services and one or more of the } \\
\text { urban specialist cancer services }\end{array}$ \\
\hline & \multirow[t]{2}{*}{ Level IV } & Rural & \multirow[b]{2}{*}{$\begin{array}{l}\text { Contextual information: Needs analysis; time relief to } \\
\text { attend five-day placement; funding to attend five-day } \\
\text { placement (salary costs of rural participants, travel and } \\
\text { accommodation, salary funding for mentor for one } \\
\text { day of placement); indemnity, legal matters, duty of } \\
\text { care, responsibility (hands-on opportunities limited by } \\
\text { indemnity issues and issues from metro staff around } \\
\text { relinquishing cancer care to practitioners with little } \\
\text { time, knowledge or skill) }\end{array}$} & \multirow[b]{2}{*}{$\begin{array}{l}\text { Positive impact: Post-programme significant improve- } \\
\text { ment in understanding of principles of chemo delivery } \\
\text { including some technical details; improved confidence } \\
\text { in technical details; knowledge translation to other } \\
\text { rural practitioners and organisations; changes in proce- } \\
\text { dures and practices; isolated incidences of improved } \\
\text { client care (less travel for clients) Considerations: } \\
\text { Programme was limited by unmet expectations; inte- } \\
\text { grating new practices with already demanding prac- } \\
\text { tice; quality and safety issues as perceived by metro } \\
\text { teachers and mentors; variability in opportunities (for } \\
\text { example some hands-on but some not, some mentor- } \\
\text { ing but some not) }\end{array}$} \\
\hline & & Australia & & \\
\hline \multirow[t]{3}{*}{ MacKinnon [65] } & \multirow{2}{*}{$\begin{array}{l}\text { Qualitative - } \\
\text { institutional } \\
\text { ethnography }\end{array}$} & \multirow[t]{2}{*}{ Nurses } & \multirow{2}{*}{$\begin{array}{l}\text { Intervention: Professional support, training and } \\
\text { education; exploration of nurses' experiences of } \\
\text { learning to provide maternity care in rural settings } \\
\text { (mode not specified) }\end{array}$} & $\begin{array}{l}\text { Primary measures: Staff outcomes - behaviour, } \\
\text { practice, knowledge, skills, job satisfaction }\end{array}$ \\
\hline & & & & $\begin{array}{l}\text { Secondary measures: Patient outcomes - safe practice; } \\
\text { service outcomes - quality }\end{array}$ \\
\hline & Level I & $\begin{array}{l}\text { Rural: less than } 10,000 \text { people } \\
\text { living beyond commuting distance } \\
\text { of an urban setting }\end{array}$ & $\begin{array}{l}\text { Contextual information: External support (example of } \\
\text { funding provided to one participant to upskill in } \\
\text { maternity care in a regional centre); accessible and } \\
\text { adequate resources; networking and relationships }\end{array}$ & $\begin{array}{l}\text { Difficult to learn about maternity in small rural } \\
\text { hospitals, in an environment where few staff members } \\
\text { are available and little education is provided; concerns } \\
\text { expressed about remaining 'experienced' and retaining } \\
\text { newly acquired skills; experienced nurses had been } \\
\text { mentored to 'learn maternity' by an experienced } \\
\text { maternity nurse; however, birth rates and staffing } \\
\text { levels have changed and such practices as mentorship } \\
\text { were no longer available for new RNs; going to a big } \\
\text { city to learn maternity nursing 'does not work' because } \\
\text { a rural hospital nurse is not able to access all the } \\
\text { 'fancy teams' and high-tech equipment available to } \\
\text { RNs working in the city; family commitments made it } \\
\text { difficult for them to leave their community for CPE }\end{array}$ \\
\hline
\end{tabular}


Table 3 Summary of papers by intervention (Continued)

Mitchell et al. [66] Mixed methods - post- Mental health practitioners intervention, action

research

Level III (Daly)

Rural and remote

Australia
Intervention: Professional support, training, education and supervision; telemedicine network established to deliver and receive educational material via

videoconferencing facilities (non-face-to-face: multi-site real-time videoconferencing)

Contextual information: Access to technology (type of technology - videoconferencing units; ensuring availability of units, ensuring adequate IT support commitment and support; ensuing funding; ensuring time available for setup; timing of programme: ensuring flexibility of delivery for staf ensuring organisational support); organisational

Primary measures: Staff outcomes - accessing the network, participation in the network, useful sessions, benefits (networking, peer support)

Positive outcomes: ability to access second opinions; ability to access specialists; ability to book

teleconsultations; ability to access supervision from Adelaide; improved networking and peer support; improved efficiency and travel costs; improved health service efficiency (due to enhanced knowledge) retention Considerations: Impediments included competition with other services for use of equipment; equipment breakdown; time required to set up a session; staff on rotating rosters not being available at a set time; difficulties with local organisational processes, including approvals; imperfect synchronisation of lip movement and audio in videoconferencing sessions; high cost of sessions involving multi-site videoconferencing

\begin{tabular}{ll}
\hline Owen et al. [67] & $\begin{array}{l}\text { Non-experimental - } \\
\text { pre- and post- } \\
\text { intervention descriptive } \\
\text { evaluation }\end{array}$
\end{tabular}

Intervention: Professional support, training and education; intermittent outreach service provided by metro mental health specialist practitioners to rura and remote areas - includes joint patient care sessions, education sessions and peer support (face to face)

Contextual information: Active involvement of stakeholders in programme design and

implementation (a representative steering committee to finalise teaching topics and oversee project comprising rural health staff, metropolitan health and education staff, rural health administration; clinics organised by local contact); external organisation of the project and intervention (research officers from the university coordinated and organised the project; project lead was a visiting specialist with a vested interest in the programme being successful); marketing of programme (flyers sent to promote education sessions; project promoted in multiple mental health venues; CVs of visiting team circulated); funding (transport costs were met by the project but salaried visiting staff were 'donated' to the project)
Far west New South Wales, Australia
Primary measures: Staff outcomes - clinical skills gained; success of education sessions; knowledge gained; attitudes. Service and client outcomes admission rates from each town to a regional centre and transfer of clients for care to regional centres; prescription rates of psychotropic drugs from 18 months prior and during the project via Pharmaceutical Benefits Scheme data

Positive impact: Education session evaluation perceived increase in knowledge by most participants; content was perceived as relevant, appropriate. Regional admission rate increased and prescriptions increased (admission rates and prescription rates not controlled statistically for any other factors so cannot

Less impact: Knowledge assessment - correct responses to mental health statements same prior to and after intervention (no change from baseline - but possibly using a poor measurement tool); before and after skills assessment (clinical vignettes); small improvement in ability to diagnose psychiatric conditions attribute to the intervention per se). 
Table 3 Summary of papers by intervention (Continued)

Schopp et al. [68]_Non-experimental - Psychologists

descriptive pre-and

post-test evaluation

Level IV

Rural: Mid-Western rural communities

\begin{tabular}{lll}
\hline Sullivan et al. [69] & $\begin{array}{l}\text { Non-experimental - } \\
\text { descriptive post- }\end{array}$ & $\begin{array}{l}\text { Medical practitioners } \\
\text { (GPs and psychiatrists }\end{array}$
\end{tabular}

(GPs and psychiatrists)

intervention evaluation

Level IV

Rural

Canada

\begin{tabular}{ll}
\hline Tumosa et al. [70] & $\begin{array}{l}\text { Non-experimental } \\
\text { descriptive pre- and }\end{array}$
\end{tabular}

post-evaluation

Level IV

Community of 5,000, 60 miles from major metropolitan areas.

Rural Kentucky, USA
Intervention: Professional support, training and

education; specialist one-on-one support and training

for remote generalist psychology clinicians through

telehealth videoconferencing and website support for

families (non-face-to-face: real-time videoconferencing)

Contextual information: Access to technology (with

ability to encrypt and decrypt data for patient

confidentiality); externally supported and organised

(participating rural practitioners, technology, content of

sessions); attributes of teacher (approachable)
Intervention: Training, education and mentoring;

shared care strategies between expert mentor and

via telephone combined with monthly education

sessions and joint clinical consultation (combination:

face to face and telephone)

Contextual information: Attributes of teacher (relaxed, expert did not take on teacher role, mentor,

approachable); needs analysis; accessible resources

(funding for travel to education sessions, time to attend sessions)

Intervention: Mentoring, training and education;

evaluation of a geriatric scholar programme for rura

primary care providers consisting of education and

training in geriatrics and gerontology and in quality

improvement (combination: face to face (clinical

practice), webinars, audio conferences)

Contextual information: Active involvement of stakeholders; organisational commitment; needs analysis (educational needs assessment); external support (financially and organisationally supported by networks of services with a 'hub site' located in a metro centre); accessible and adequate resources

(intranet web-based platform to share resources as a

learning community); networking and relationships;

ongoing evaluation and feedback opportunities (iden-

tification of additional learning resources)
Primary measures: Staff outcomes - knowledge gains: to tient outcomes - client satisfaction, family access va structured interview

Positive impact: Significant pre- and post-test scores for clinicians for knowledge gain (and self-reported confidence) (means not given). Patients found trained clinicians helpful and knowledgeable. Compared to the 11 patients who chose not to use the trained clinician, authors report trained providers were perceived as more helpful and more knowledgeable than untrained providers - this was reported as significant (the statistical analyses of patient responses when comparing trained with untrained clinicians is flawed, thus we cannot rely on these results)

Primary measures: Staff outcomes - identify key

success factors to shared care in this manner-

measured one year after the pilot project

Positive impact: Mentoring: All physicians viewed mentoring as highly valuable and a preferred method for accessing advice; allowed them to continue their own clinical interventions confidently, which they would not be able to support otherwise. Education: More satisfied if content relevant and if teacher utilised a relaxed approach to teaching

Primary measures: Staff outcomes - practice behaviour, knowledge, skills, 'usefulness of programme' Secondary measures: Service outcomes - quality improvement, perceived impact on patient care

Positive impact: Improvements in self-reported competence and self-confidence in geriatric skills, topics and knowledge (and a resulting perceived change in practice). decline in continuing need for further education: high completion rates of $\mathrm{Q}$ projects; development of a rich learning community 
Table 3 Summary of papers by intervention (Continued)

Papers specifically examining mode of delivery

\begin{tabular}{|c|c|c|c|c|}
\hline \multirow{4}{*}{$\begin{array}{l}\text { Gagnon and } \\
\text { Minguet [71] }\end{array}$} & \multirow{2}{*}{$\begin{array}{l}\text { Non-experimental - } \\
\text { pre- and post-test pilot } \\
\text { study evaluation }\end{array}$} & \multirow[t]{2}{*}{ Medical practitioners } & \multirow{2}{*}{$\begin{array}{l}\text { Intervention: Professional support, training and } \\
\text { education; use of internet for delivery of online } \\
\text { courses and collaboration with online tutorial sessions } \\
\text { delivered twice weekly (non-face-to-face: virtual } \\
\text { classes, collaborative web conferencing, real-time chat) }\end{array}$} & Primary measures: Staff outcomes - gain in knowledge \\
\hline & & & & $\begin{array}{l}\text { Secondary measures: Staff outcomes - level of comfort } \\
\text { with IT }\end{array}$ \\
\hline & \multirow[t]{2}{*}{ Level IV } & Rural and remote & \multirow{2}{*}{$\begin{array}{l}\text { Contextual information: Access to technology (internet, } \\
\text { computer, interactive IT programmes, webcam, } \\
\text { microphone, software development, running and } \\
\text { analysis); attributes of coach (availability); structure and } \\
\text { content of programme (two tutorial sessions per week } \\
\text { with real-time conversations online, virtual classes with } \\
\text { real-time chatting and asynchronous exchange); cor- } \\
\text { rect use of technology and ability to use technology; } \\
\text { external support and organisation }\end{array}$} & $\begin{array}{l}\text { Positive impact: Reported the experience had brought } \\
\text { them out of isolation and enabled very productive } \\
\text { contacts with peers; participants likely to gain } \\
\text { pedagogic knowledge and to maintain this knowledge } \\
\text { over time }\end{array}$ \\
\hline & & Canada (Quebec); France & & $\begin{array}{l}\text { Less impact: Perception of level of comfort with } \\
\text { information and communication technologies was } \\
\text { unlikely to change }\end{array}$ \\
\hline $\begin{array}{l}\text { Stewart and } \\
\text { Carpenter [72] }\end{array}$ & $\begin{array}{l}\text { Qualitative - action } \\
\text { research }\end{array}$ & Physiotherapists & $\begin{array}{l}\text { Intervention: Twice weekly iChat with mentor and } \\
\text { monthly videoconferencing with mentor and other } \\
\text { mentees for three months (non-face-to-face: } \\
\text { asynchronous chat, iChat, email, real-time }\end{array}$ & $\begin{array}{l}\text { Primary measures: Staff outcomes - effectiveness of } \\
\text { mentoring using this medium; experience with } \\
\text { technology }\end{array}$ \\
\hline
\end{tabular}

Level III Rural

videoconferencing)

Contextual information: Active involvement of stakeholders in programme design and

implementation (measuring success and evaluating effectiveness of programme at key intervals and changing programme in response to feedback ); access to technology (Mac laptops with appropriate programmes; IT support; easy to use); mentor and mentee attributes (relationship between mentor and mentee); externally organised and supported

\begin{tabular}{llll}
\hline Chipps et al. [73] & $\begin{array}{l}\text { Non-experimental - } \\
\text { descriptive pre- and } \\
\text { post-evaluation }\end{array}$ & Medical practitioners (psychiatry) & $\begin{array}{l}\text { Intervention: Videoconference-based psychiatry regis- } \\
\text { trar training programme (non-face-to-face: real-time } \\
\text { videoconferencing) }\end{array}$ \\
& Level IV & $\begin{array}{l}\text { Urban and rural } \\
\text { Contextual information: Accessible and adequate } \\
\text { resources; networking and relationships } \\
\text { (videoconferencing was real time with participant } \\
\text { interaction) }\end{array}$
\end{tabular}

Positive impact: Improved communication (ichat sessions replicated the colleague interaction that was generally missed in sole positions); improved clinica reasoning, confidence and knowledge translation Primary measures: Attendance; familiarity with videoconferencing; cost and time savings; appropriateness of content and mode, technical issues Positive outcomes: Improved access to education (increased attendance and reduction in travel resulting in time and cost savings); videoconferencing perceived as appropriate educational tool (and as effective as face-to-face teaching); videoconferencing gave satisfactory interaction

Considerations: technical issues audio quality 
Table 3 Summary of papers by intervention (Continued)

Brownlee et al. [15] Qualitative - thematic Social workers

analysis of interviews

Level III

Rural and remote: Practitioners

from areas where the population

densities are well below 400 people/kn²

Canad
Intervention: Perception of utility of different

technologies for supporting social work practice in

rural areas (non-face-to-face: chat, email, internet,

videoconferencing)

Contextual information: Accessible and adequate

resources (internet access, email, caseload database

systems, phone systems, for example, telehealth)
Primary measures: Staff outcomes - use of technology, change in practice behaviour, connectedness

Positive impact: Professional networking; clinical feedback; supervision and access to services seem to have increased with the availability and use of the internet

Considerations: Not all use internet - language barriers; cumbersome and confusing; not all challenges of rural practice have been remedied, by the internet - for example dual relationships in small rural towns 
Table 4 Nature of the literature

\begin{tabular}{|c|c|}
\hline Component & $\begin{array}{c}\text { Number of } \\
\text { papers }\end{array}$ \\
\hline \multicolumn{2}{|l|}{ Intervention } \\
\hline Training and education ${ }^{a}$ & 20 \\
\hline Combination & 9 \\
\hline Professional support & 4 \\
\hline Supervision & 4 \\
\hline Technology focus & 4 \\
\hline Mentoring & 2 \\
\hline \multicolumn{2}{|l|}{ Professional groups } \\
\hline Nursing & 9 \\
\hline Allied health & 5 \\
\hline Pharmacists & (1) \\
\hline Physiotherapists & (2) \\
\hline Psychologists & (1) \\
\hline Social workers & (1) \\
\hline Medics and general practitioners & 8 \\
\hline Multi-disciplinary (>3 professions) & 8 \\
\hline Other ${ }^{b}$ & 5 \\
\hline Combination & 5 \\
\hline Nursing + dietitians & (1) \\
\hline Nursing + general practitioner/medic & (2) \\
\hline $\begin{array}{l}\text { Mental health practitioner + general } \\
\text { practitioner }\end{array}$ & (1) \\
\hline Psychologists + social workers & (1) \\
\hline Mental health practitioners & 3 \\
\hline \multicolumn{2}{|l|}{ Country } \\
\hline Australia & 20 \\
\hline Canada & 10 \\
\hline United States of America & 7 \\
\hline Guatemala & 1 \\
\hline Kenya & 1 \\
\hline New Zealand & 1 \\
\hline South Africa & 1 \\
\hline United Kingdom & 1 \\
\hline
\end{tabular}

${ }^{\mathrm{a}}$ Training and education: Continuing Professional Education (CPE), Continuing Medical Education (CME), Continuing Professional Development (CPD); badministrative staff, palliative carers, Aboriginal health workers, health workers, community members, spouses.

to support practitioners to undertake support opportunities (for example, see Healey-Ogden [40]).

Mentoring includes interventions where the delivery of a mentoring programme was the primary focus of the paper.

There was also a collection of studies that specifically examined the mode of delivery of an intervention rather than the intervention per se. These studies are outlined in Table 3 and are explored further (below) as a contextual mechanism.

\section{Defining success: measures used to examine the effect of support interventions on patient, staff and service outcomes}

Successful support interventions were found to be those that positively influence or enhance patient, service and/ or staff outcomes. Table 3 describes the outcomes measured for each study and Table 5 summarises the outcomes used to characterise success.

Staff outcomes were measured most frequently, generally through self-report measures such as self-reported gains in knowledge, competence and skill and/or clinical practice. Other staff outcomes included: gains in knowledge (tested via knowledge tests), feelings of isolation or socialisation (for example, connectedness with other centres or colleagues), levels of information exchange and networking, and retention (intention to leave and staff turnover).

Programme outcomes were also examined and included satisfaction with the programme (relevance, ease of use, ease of access and fulfilling needs), attendance and participation levels and numbers, and level of comfort or competence with technology.

Service outcomes were most frequently reported around perceived improvement in quality, safety of care and higher standards of practice. These outcomes were often also cited as patient outcomes. Other service outcomes included changes in the organisational culture and improvements in access to care and clinic efficiency.

There were four cases where patient outcomes were reported. These included staff perceptions of improvements in screening procedures for clients, improved access to and quality of services, reduced number of transfers of care from rural to regional centres, improved client satisfaction with services and the completeness of health information and services received by clients.

\section{Mechanisms specific to rural and remote contexts and their relation to outcomes}

A total of ten mechanisms were identified. These are outlined in Table 6. The mind map of the relation between mechanisms and outcomes is illustrated in Figure 2.

\section{Conducting a needs analysis prior to intervention}

White et al. [58] described a government-run CME programme where an annual educational needs analysis questionnaire was distributed to all rural and remote general practitioners (GPs) to inform them of the programme. The authors reported that access to CME contributes to confidence in practising in rural and remote areas, CME strongly alleviates professional isolation and GPs are less likely to remain in practice without access to CME. 
Table $\mathbf{5}$ Summary of outcomes utilised to characterise success

\begin{tabular}{|c|c|}
\hline Outcome & Studies examining outcome \\
\hline \multicolumn{2}{|l|}{ Service outcomes } \\
\hline Perceived improvement in quality, safety of care or higher standards of practice & $15,39,41,47,49,54,70,71,77$ \\
\hline Change in organisational culture & $34,36,37,44$ \\
\hline Improvement in access to care and clinic efficiency (perceived) & $4153,56,76$ \\
\hline Improved 'actioning' of issues & 33,34 \\
\hline Increased certification of practitioners & 74 \\
\hline Cost and time savings & 71 \\
\hline Reduction in travel & 71 \\
\hline Improved referral pathways, connections or collaboration & 66 \\
\hline \multicolumn{2}{|l|}{ Staff (including programme) outcomes } \\
\hline $\begin{array}{l}\text { Increases in self-reported knowledge, confidence and competence in practice, skills and/or clinical } \\
\text { decision-making }\end{array}$ & $\begin{array}{l}15,33,41,44,46,48,49,52,54,59,60,61,71, \\
72,75,76\end{array}$ \\
\hline $\begin{array}{l}\text { Content or structure of material or programme perceived as appropriate and relevant by } \\
\text { participants }\end{array}$ & $44-46,49,53,54$ \\
\hline Retention of staff & $39,40,49,66,75$ \\
\hline Greater understanding of role of mentoring or supervision & $37,36,44$ \\
\hline Capacity to attend or participate in programme & 49,52 \\
\hline Improved collaboration with other health workers & 41 \\
\hline Knowledge gains & 14,34 \\
\hline Improved attitude towards supervision or mentoring & 36,37 \\
\hline Job satisfaction & 15,71 \\
\hline Improved staff well-being & 43 \\
\hline Improved knowledge of roles and knowledge sharing & 54 \\
\hline Improved reflective practice & 66 \\
\hline \multicolumn{2}{|l|}{ Programme outcomes } \\
\hline Attendance and completion rates & $14,33,34,36,37,43,45,54,57,59,72,76$ \\
\hline Sustainability of programme & $34,36,37,43,47,48,54,56$ \\
\hline Knowledge translation to other rural practitioners and organisations & $48,54,76$ \\
\hline Engagement with the programme & $33,54,59$ \\
\hline Satisfaction with the programme (including perceived positive use of staff time) & $33,52,66$ \\
\hline Attainment of learning goals & 49,52 \\
\hline \multicolumn{2}{|l|}{ Patient outcomes } \\
\hline Staff perceived improvements in screening procedures & 41 \\
\hline $\begin{array}{l}\text { Reduced admission rates from a rural to a regional centre and reduced transfer of clients for care to } \\
\text { regional centres }\end{array}$ & 53,76 \\
\hline Client satisfaction with services & 61 \\
\hline Improved quality and completeness of health information and services received by clients & 56 \\
\hline
\end{tabular}

On a more individual level, Tumosa et al. [70] described a programme of rural education that requires participants to complete a survey to assess individual educational needs. The needs analysis was used to then design an appropriate mix of clinical, didactic, supervised and administrative learning experiences. Participants reported high levels of educational goal achievement from participation in the programme.
A needs analysis prior to intervention was linked to the following outcomes: improved service outcomes including improved access to services, improved quality of services and more sustainable programmes; and positive staff outcomes such as perceived appropriateness of programme, perceived positive use of staff time, confidence in practicing in rural and remote areas, higher programme attendance levels, positive influence on perceived clinical 
Table 6 Key mechanisms identified from synthesis of evidence

\begin{tabular}{|c|c|c|c|c|c|c|c|c|c|}
\hline $\begin{array}{l}\text { Evidence } \\
\text { (reference) }\end{array}$ & $\begin{array}{l}\text { Active } \\
\text { involvement of } \\
\text { stakeholders }\end{array}$ & $\begin{array}{l}\text { Organisational } \\
\text { commitment }\end{array}$ & $\begin{array}{l}\text { Access to } \\
\text { training, skills } \\
\text { or knowledge } \\
\text { for the } \\
\text { intervention }\end{array}$ & $\begin{array}{l}\text { Needs } \\
\text { analysis }\end{array}$ & $\begin{array}{l}\text { External } \\
\text { support }\end{array}$ & $\begin{array}{l}\text { Regular } \\
\text { feedback and } \\
\text { evaluation } \\
\text { opportunities }\end{array}$ & $\begin{array}{l}\text { Marketing } \\
\text { of the } \\
\text { programme }\end{array}$ & $\begin{array}{l}\text { Accessible } \\
\text { and } \\
\text { adequate } \\
\text { resources }\end{array}$ & $\begin{array}{l}\text { Networking } \\
\text { and } \\
\text { relations }\end{array}$ \\
\hline $\begin{array}{l}\text { Brambila et al. } \\
\text { [44] }\end{array}$ & $\sqrt{ }$ & & & $\sqrt{ }$ & $\sqrt{ }$ & & & $\sqrt{ }$ & \\
\hline Buckley et al. [45] & & & & & & & & $\sqrt{ }$ & \\
\hline Butcher [60] & & & $\sqrt{ }$ & $\sqrt{ }$ & $\sqrt{ }$ & & & $\sqrt{ }$ & \\
\hline $\begin{array}{l}\text { Conger and } \\
\text { Plager [37] }\end{array}$ & & & & & & & & $\sqrt{ }$ & $\sqrt{ }$ \\
\hline $\begin{array}{l}\text { Cunningham et al. } \\
\text { [47] }\end{array}$ & & $\sqrt{ }$ & & & & & & & \\
\hline Dalton et al. [62] & & & $\sqrt{ }$ & & & & & & \\
\hline D'Souza [48] & & & & & & & & $\sqrt{ }$ & \\
\hline $\begin{array}{l}\text { Gagnon and } \\
\text { Minguet [71] }\end{array}$ & & & & & & & & $\sqrt{ }$ & \\
\hline Gibb et al. [61] & $\sqrt{ }$ & & & $\sqrt{ }$ & $\sqrt{ }$ & $\sqrt{ }$ & & & \\
\hline $\begin{array}{l}\text { Glazebrook et al. } \\
\text { [50] }\end{array}$ & & & & & $\sqrt{ }$ & & & & $\sqrt{ }$ \\
\hline $\begin{array}{l}\text { Haythornthwaite } \\
\text { [52] }\end{array}$ & & & & & $\sqrt{ }$ & & & $\sqrt{ }$ & \\
\hline Hoon et al. [64] & & & & $\sqrt{ }$ & & & & & \\
\hline Kelley et al. [54] & & & $\sqrt{ }$ & & & & & & $\sqrt{ }$ \\
\hline King et al. [53] & & & $\sqrt{ }$ & & & $\sqrt{ }$ & & & \\
\hline $\begin{array}{l}\text { Lynch and } \\
\text { Happell [33,34] }\end{array}$ & $\sqrt{ }$ & $\sqrt{ }$ & $\sqrt{ }$ & $\sqrt{ }$ & & $\sqrt{ }$ & $\sqrt{ }$ & & \\
\hline Mitchell et al. [66] & & $\sqrt{ }$ & & & & & & & \\
\hline
\end{tabular}

[56]

\begin{tabular}{llllll}
\hline Owen et al. [67] & $\sqrt{ }$ & $\sqrt{ }$ & $\sqrt{ }$ & \\
\hline Schoo et al. [57] & $\sqrt{ }$ & $\sqrt{ }$ & $\sqrt{ }$ & $\sqrt{ }$ & \\
\hline Schopp et al. [68] & & & $\sqrt{ }$ & & $\sqrt{ }$ \\
\hline Stewart and & $\sqrt{ }$ & & $\sqrt{ }$ & $\sqrt{ }$
\end{tabular}

Carpenter [72]

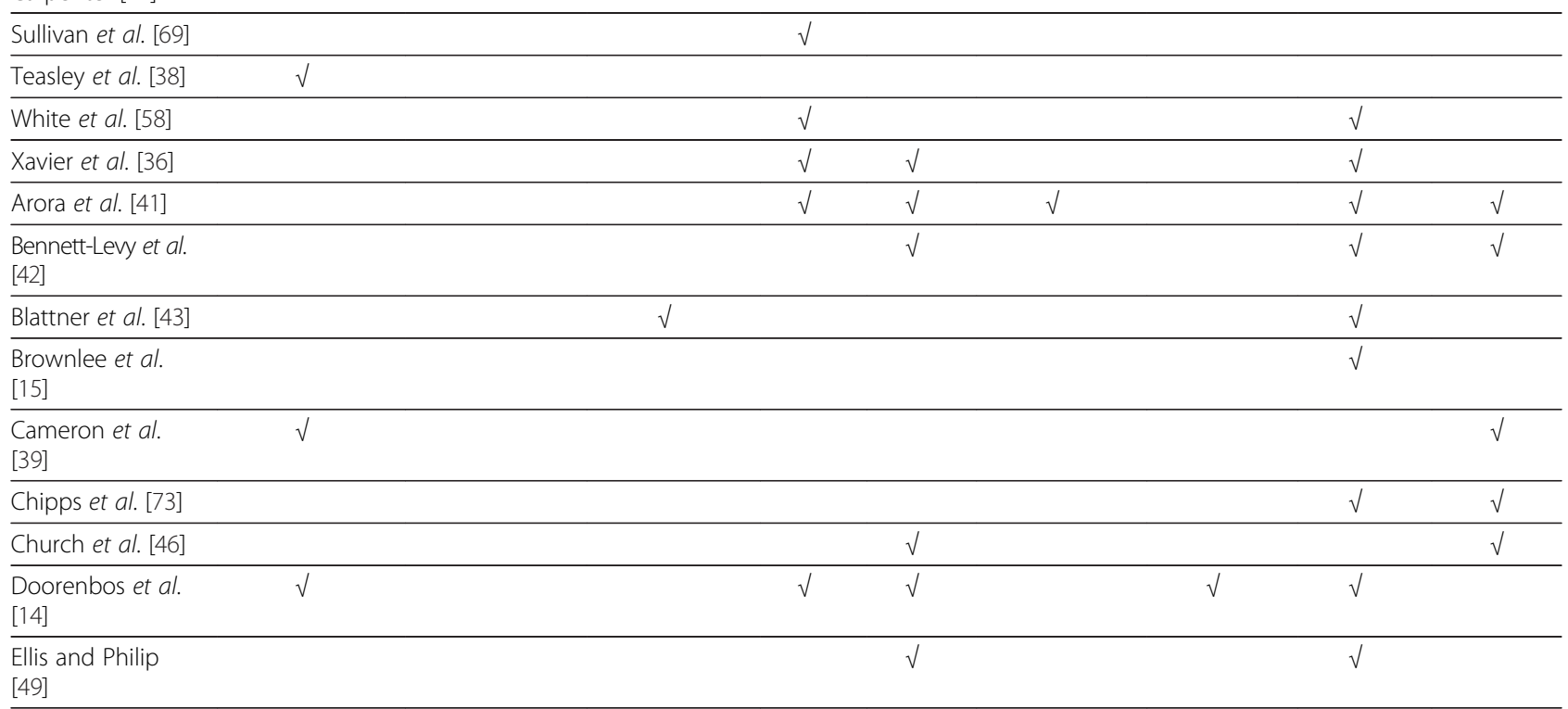


Table 6 Key mechanisms identified from synthesis of evidence (Continued)

\begin{tabular}{|c|c|c|c|c|c|c|}
\hline English et al. [35] & $\sqrt{ }$ & $\sqrt{ }$ & $\sqrt{ }$ & $\sqrt{ }$ & & $\sqrt{ }$ \\
\hline Gardner et al. [75] & & & & $\sqrt{ }$ & $\sqrt{ }$ & $\sqrt{ }$ \\
\hline $\begin{array}{l}\text { Gorsche and } \\
\text { Woloschuk [51] }\end{array}$ & & & & $\sqrt{ }$ & $\sqrt{ }$ & \\
\hline $\begin{array}{l}\text { Healey- } \\
\text { Ogden et al. [40] }\end{array}$ & & $\sqrt{ }$ & $\sqrt{ }$ & $\sqrt{ }$ & $\sqrt{ }$ & \\
\hline $\begin{array}{l}\text { Koczwara et al. } \\
{[55]}\end{array}$ & & & $\sqrt{ }$ & $\sqrt{ }$ & $\sqrt{ }$ & $\sqrt{ }$ \\
\hline MacKinnon [65] & & & & $\sqrt{ }$ & $\sqrt{ }$ & $\sqrt{ }$ \\
\hline Tumosa et al. [70] & $\sqrt{ }$ & $\sqrt{ }$ & $\sqrt{ }$ & $\sqrt{ }$ & $\sqrt{ }$ & $\sqrt{ }$ \\
\hline Wright et al. [59] & & & $\sqrt{ }$ & $\sqrt{ }$ & $\sqrt{ }$ & $\sqrt{ }$ \\
\hline
\end{tabular}

skills and confidence in performing clinical interventions that they would not otherwise be able to support.

\section{Active involvement of stakeholders in programme design, implementation and evaluation}

Gibb et al. [61] used an action research approach to develop an organisational definition of mentoring and to identify the qualities valued in a mentor. The findings from this action cycle were converted into questionnaires by a research team. The results of the questionnaires were used to develop a set of guidelines regarding qualities desired in mentors and mentees, as well as an evaluation tool for monitoring the mentoring relationship.

Actively involving stakeholders in programme design, course or programme content, implementation and evaluation was linked to: positive changes in organisational culture towards supervision, a better understanding of the role of mentoring and supervision, higher participation levels in the programme, a perception that the content and structure of the material or programme were appropriate

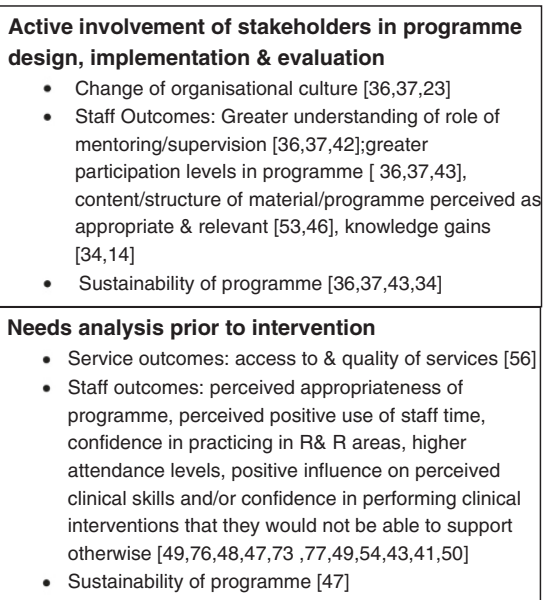

- Sustainability of programme $[36,37,43,34]$

Needs analysis prior to intervention

- Service outcomes: access to \& quality of services [56]

- Staff outcomes: perceived appropriateness of programme, perceived positive use of staff time, confidence in practicing in $R \& R$ areas, higher attendance levels, positive influence on perceived clinical skills and/or confidence in performing clinical interventions that they would not be able to support otherwise $[49,76,48,47,73,77,49,54,43,41,50]$

- Sustainability of programme [47]

\section{External support, organisation, facilitation \&/or coordination of programme \\ -Staff outcomes: Greater participation levels in programme/course completion rates [57,51], improved reflective practice [66], enhanced skills [ $75,65,66]$, \\ retention of staff $[65,49]$ \\ -Sustainability of the programme (e.g. through sustained funding) [47]}

\section{Marketing of the programme \\ - Organisational commitment $[36,37]$ \\ - Greater participation levels $[36,37]$}

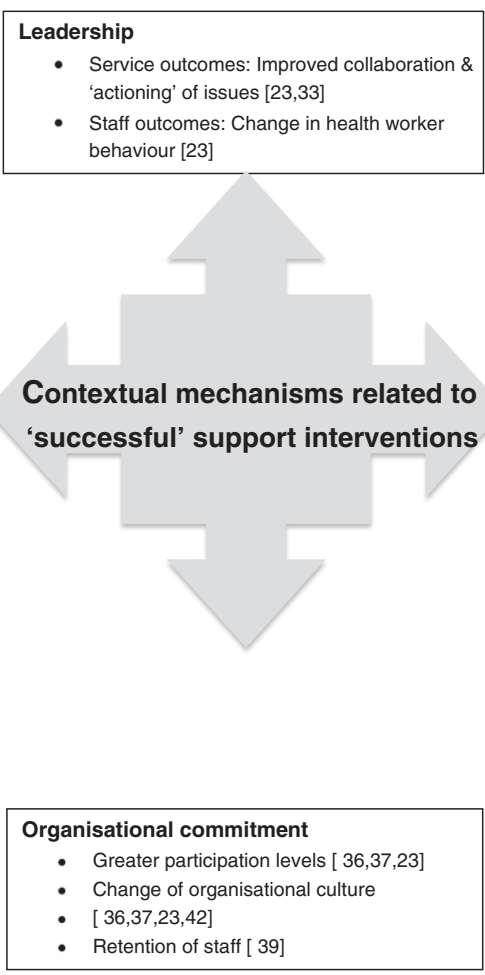

Networking \& Supportive relationships

- Greater impact on staff outcomes: job satisfaction/staff wellbeing (being supported or connected) when working as a rural/remote practitioner [70], satisfaction with the programme $[33,66,75]$, high attendance rates \& engagement with the programme $[54,33,59]$, improved knowledge of roles \& knowledge sharing [ 54] retention of health workers [66], improved collaboration with other health professionals [41], improved competence [41]

Access to training/skills/knowledge to perform supervision/ education and/or mentoring

- Sustainability of programme $[56,48]$

- Improved attitude to supervision/mentoring [ 36,37$]$

- Staff outcomes: perceived increases in self-reported knowledge, confidence in practice and skills [ 48,71]

Regular feedback \& evaluation opportunities

- Staff outcomes: Greater participation levels [15,43], programme perceived as relevant and useful - $[54,45,42,49]$

Figure 2 Mind map of key mechanisms and their relation to outcomes. 
and relevant, higher and sustained attendance and increased sustainability of the programme.

\section{External support, organisation, facilitation and/or coordination of programme}

Action research, for example, involving support from university researchers can contribute to successful outcomes. One study describes how university researchers assisted a service to implement a continuing education (CE) programme for physiotherapists in rural Victoria, Australia [57]. Researchers developed a questionnaire to assess the CE needs of physiotherapists. The results then informed the development of a CE programme and programme evaluation tools. All targets for success (as identified and defined by stakeholders) were reached.

External support, organisation, facilitation and/or coordination of the programme were linked to the following outcomes: good programme attendance rates and successful knowledge translation between colleagues.

\section{Organisational commitment and leadership}

Strong organisational commitment has been linked to: greater participation levels, change in organisational culture, sustainable programmes and improved patient outcomes and quality of service provision. Leadership and organisational commitment to a newly developed supervision programme, as demonstrated by a senior management team forming a clinical supervision committee to oversee implementation and evaluation of the staff-led supervision programme [33,34], was reported to lead to a large change in culture in relation to supervision within the mental health programme. The successful adoption of best practices in rural Kenyan hospitals was related to the implementing team, hospital management, and facilitator together provided leadership and supported a shift in organisational culture and commitment that helped motivate health workers and change their individual behaviours' (p. 4) [35].

\section{Accessible and adequate resources}

Having access to adequate and appropriate resources (including time) to undertake or provide support programmes has been linked to greater success implementing support programmes and potentially retention of staff.

Significantly greater retention rates for rural medical practitioners have been achieved through the provision of fully subsidised locum-relieved training programmes [51]. Greater retention of nursing staff following the implementation of an 80/20 staffing model in a rural hospital has also been reported [40]. The 80/20 model provides staff with $20 \%$ of their salaried time off from direct patient care in order to pursue various types of professional development activities. Importantly backfill positions were created to accommodate the $20 \%$ reduction in clinical duties.

Having access to adequate and appropriate resources was also linked to high levels of staff satisfaction with the intervention or programme and the mode of delivery of the intervention.

\section{Mode of delivery, format and timing}

Perceptions of greater programme success were associated with a mentoring programme when three key elements were addressed: timing (twice weekly 'chat' with monthly videoconference); mode of delivery (iChat, videoconference and email); and format ('chat' mentoring weekly and videoconferencing where mentees take turns) [72]. It was perceived, for example, that electronic iChat sessions replicated the colleague interaction that was generally missed in sole positions.

Where the format of a support programme included opportunity for interaction, networking and/or peer support, there was a relation with successful outcomes such as reduced feelings of isolation, high access rates, completion of and participant satisfaction with the programme. This was the case for both face-to-face $[46,47,54,59]$ and non-face-to-face interventions [72].

A randomised controlled trial examining the impact of an accredited online training program in CBT for rural and metropolitan psychologists, compared structured online modules of study with or without support from a CBT expert [42]. The supported training group was significantly more likely to finish all training modules than the group that undertook the training without support. An online resource for rural health-care practitioners that was supplemented by online, facilitated modules also demonstrated high access rates [55].

Where the mode of delivery was face to face, provision of funding and support (for travel, accommodation, salary, time and locum relief $[50-52,58,65,67])$ related to successful outcomes including sustainability of (and ability to conduct) the programme and participation rates. This was also the case for non-face-to-face interventions where funding was essential to equipment provision and payment of participating specialists, teachers, mentors and supervisors $[41,42,66]$.

For face-to-face interventions, where the programme was delivered, for example in a local or regional centre $[44,50,54,57,65]$, was also important, relating to successful outcomes such as capacity to attend the programme.

When interventions were delivered remotely utilising technology, the following elements were identified that related to successful outcomes: flexibility in the timing of delivery $[15,48,59,66]$; adequate preparation for technology to work [56], such as an orientation to the technology and online learning approach [41]; external support and coordination (including organisation of technology and 
participants, and development or organisation of the content of sessions) $[14,36,41,46,55,56,68,71-73]$; ease of use of technology (including adequate connection speeds) $[15,41,42,52,55,56,59,62,66,71,73,74]$; correct use of technology and ability to use technology $[41,45,46,52,62,71,73]$; confidential transmission of patient details, information and case histories $[41,45,66,68,72]$; and willingness of participants to undertake self-directed learning [42,59,62]. These elements related to success factors including the sustainability of the programme, participation rates and participant satisfaction levels.

The importance of addressing these elements was illustrated by Mitchell et al. [66], who reported satisfaction with and the overall success of technologically driven interventions can be impeded by: competition with other services for use of the equipment; equipment breakdown; the time required to set up a session; staff on rotating rosters not being available at a set time; difficulties with local organisational processes, including approvals; the imperfect synchronisation of lip movement and audio in videoconferencing sessions; and the high cost of sessions involving multi-site videoconferencing. These mechanisms are important for a successful online format.

\section{Access to training, skills or knowledge for supervision, education or mentoring}

Ensuring access to training, skills or knowledge for supervision, education, training or mentoring has been linked to the sustainability of a programme, an improved attitude to supervision or mentoring and an increased effect on staff outcomes (perceived increases in self-reported knowledge, confidence in practice and skills). One element of a successful staff-led supervision programme was to ensure that all supervisors and supervisees received external training in supervision [33,34].

\section{Regular feedback and evaluation of the programme}

Regular feedback and evaluation of support programmes has been linked to improved knowledge translation, sustainability of the programme and greater effect on staff outcomes. The importance of measuring success and evaluating the effectiveness of a programme at key intervals and changing the programme in response to feedback was demonstrated in a study of electronic mentoring of rural paediatric physiotherapists [72]. The study demonstrated improved communication between mentor and mentees and improved clinical reasoning, confidence and knowledge translation.

\section{Marketing of the programme}

Officially launching a supervision programme, as described in two studies, had a twofold effect: (i) it demonstrated organisational commitment and (ii) it increased awareness of and participation in the programme [33,34].

\section{Networking and supportive relationships}

Networking and supportive relationships refer to networking opportunities, peer relationships, relationships with experts and specialists and relationships with the community. They are linked with high levels of participant satisfaction with the intervention or programme, greater attendance rates, improved knowledge of roles, retention of health workers, improved quality or safety of practice and improved reflective practice.

Retention of GPs for longer than a four-year period across four rural communities in Canada was found to be related to community factors such as appreciation shown by the community for the practitioner and community connection or a sense of belonging and integration into the community [39]. The absence of supportive relationships has been related to declining birth rates in rural areas, because there were fewer trained staff to provide maternity services. One study describes how scant access to birthing experiences and therefore experienced mentors for new nurses to gain this experience, restricts access to maternity services for rural clients [65].

\section{Discussion}

This synthesis has identified a number of support interventions for health-care practitioners in rural and remote contexts, the outcomes that such interventions can generate and has identified mechanisms, specific to rural and remote contexts, that relate to successful outcomes for staff, patients and services.

We identified that the outcomes of support interventions for practitioners in rural and remote contexts may be enhanced if the support strategy includes: consultation with staff prior to the programme to assess individual, collective and context specific needs; external support; accessible and adequate resources assisting staff to undertake or access the programme; and interactive and networking opportunities.

Professional networking, education and supervision opportunities for rural and remote health-care practitioners have increased with the availability and use of the internet [15]. We found that for programmes delivered remotely using technology, outcomes such as engagement with the programme, reduction of feelings of isolation, achievement of learning outcomes and knowledge gains and participant satisfaction may be further enhanced if there is a 'human element' to the programme, such as networking opportunities, online facilitation and/or interactive learning elements. Interactive techniques have been shown elsewhere to be the most effective educational technique for changing physician care and influencing 
patient outcomes [8]. However, to gain such benefits, the format and timing of the technologically driven support strategy also need to be carefully considered such that they are user friendly and flexible enough to be accessed by participants at convenient times.

Most importantly, in rural and remote contexts the evidence suggests that supporting practitioners to access support interventions by means of financial reimbursement, travel subsidies, backfilling and organisational commitment can directly or indirectly influence retention of staff and the quality and safety of services.

A recent meta-synthesis of recruitment and retention of occupational therapists and physiotherapists in rural regions supports these findings. Support from the organisation influences retention and with support, challenges can become rewards and assets [17]. These findings are also consistent with Humphreys and colleagues' research examining the relation between education, training and retention of the rural primary health-care workforce [23]. Furthermore it has been demonstrated that without organisational commitment, efforts to change clinical practice by influencing individuals is ineffective [75].

This review has attempted to capture the complexity of the mechanisms required in a rural and remote context to operationalise a successful support intervention for healthcare practitioners. We therefore chose not to exclude research on the basis of quality, opting instead to extract a fuller understanding of 'relationships, mechanisms and meaning' within the evidence base [27]. This form of exploration is something a traditional systematic review is limited in performing [31], particularly in rural and remote contexts [20], despite or because of inclusion of high-quality research. As such, both approaches have their limitations.

The most rigorous sources of evidence included in this review were also the leanest on contextual and mechanism data. For example, Gorsche and Woloschuk conducted a longitudinal matched case-control study [51] that importantly found that retention of rural and remote GPs can be significantly enhanced through provision of training. The mechanisms that produced this result, however, are not clear. On the other hand, Healey-Ogden et al. [40] described a number of mechanisms that lend support to the premise that financially supporting professional development opportunities can lead to retention of staff; however, the study is of low quality.

There is an inherent difficultly therefore in balancing scientific rigour with identification, exploration and reporting of contextual elements that may influence the outcome of a support intervention in a complex context such as the rural and remote health-care environment.

\section{Study limitations}

There was a dominance of literature pertaining to education and training interventions and a dearth of literature evaluating support, supervision and mentoring interventions. The mechanisms identified in this review may, therefore, not reflect the entirety of mechanisms required for successfully supporting health practitioners in rural and remote health-care contexts.

This limitation may have been partially addressed through the undertaking of additional hand searches of cited reference lists or searches within the grey literature. Neither of these strategies, however, were undertaken for this review.

Measures of success in this review have been influenced by the nature of the research methodologies and corresponding measurement tools employed by the reviewed papers. There was an overrepresentation, for example, of papers that measured the success of an intervention in terms of self-reported staff outcomes such as knowledge, skill or confidence gains utilising unvalidated questionnaires.

The review has focussed on identifying relations between contexts, mechanisms and outcomes. Although an integrative review methodology and thematic analysis were employed, further research investigating these relations may be strengthened by the use of inductive logic reasoning [76]. This combines programme logic [30], realistic evaluation [27] and other structure-process-outcome models to extract and organise the data systematically under the headings: drivers, contexts, mechanisms (barriers and facilitators), outputs and outcomes.

\section{Further research}

Despite the importance of enabling and facilitating access to support for health-care practitioners in rural and remote contexts, the capacity of a practitioner to access a support intervention was rarely used as a measure of success nor were the factors that facilitated or hindered a practitioner from accessing support explored. Attendance rates or completion rates of the intervention were proxies. There was also little information on the effect of supervision interventions on any outcomes. Equally, only four papers identified the retention of health workers as an outcome of interest.

\section{Conclusion}

Through synthesis of the literature, this research has identified a number of key mechanisms that are associated with successful support interventions for health-care practitioners in rural and remote health-care contexts. In particular, there is a need for health-care organisations to make a commitment to actively enable practitioners in rural and remote contexts to access support interventions.

This review has identified a need for better quality research, in particular research assessing supervision interventions and retention as an outcome of support strategies, to enable more concrete conclusions to be drawn regarding 
the direct effect of support interventions for rural and remote health-care practitioners on staff, patient and service outcomes.

\section{Abbreviations}

ARIA: Accessibility/Remoteness Index of Australia; CBT: cognitive behavioural therapy; CE: continuing education; CME: continuing medical education; CPD: continuing professional development; CPE: continuing professional education; GP: general practitioner; NHMRC: National Health and Medical Research Council (of Australia); RRMA: Rural Remote and Metropolitan Areas; WHO: World Health Organisation.

\section{Competing interests}

The authors declare that they have no competing interests.

\section{Authors' contributions}

JY carried out the literature searches. AM and JY carried out the initial screening process. AM, JC, RP, DB and JY screened all papers for inclusion. AM carried out the thematic analysis and wrote the paper. $\mathrm{SN}$ assisted with thematic analysis and advised on the theoretical approach. AM conceived the study and drafted the initial manuscript. JC, RP, DB, JY and SN participated in its design and coordination and helped to draft and review the manuscript. All authors read and approved the final manuscript.

\section{Acknowledgements}

This research was made possible through funding provided by the New South Wales Department of Health in partnership with the Greater Southern Area Health Service (Southern and Murrumbidgee Local Health Districts).

\section{Author details}

${ }^{1}$ Centre for Inland Health, Charles Sturt University, PO Box 789, Albury, NSW 2640, Australia. ${ }^{2}$ School of Health and Human Sciences, Southern Cross University, PO Box 157, Lismore, NSW 2480, Australia.

Received: 22 August 2013 Accepted: 28 January 2014 Published: 13 February 2014

\section{References}

1. NSW Health: Rural Hospital and Health Service Program. Sydney; 2013

2. Struber JC: Recruiting and retaining allied health professionals in rural Australia: why is it so difficult? Internet I Allied Health Sci Pract 2004, 2(2):1-13.

3. Productivity Commission: Australia's Health Workforce. Canberra; 2005.

4. O'Toole K, Schoo AM: Retention policies for allied health professionals in rural areas: a survey of private practitioners. Rural Rem Health 2010, 10(2):1331.

5. O'Toole K, Schoo A, Hernan A: Why did they leave and what can they tell us? Allied health professionals leaving rural settings. Aust Health Rev 2010, 34(1):66-72.

6. Stagnitti K, Schoo A, Dunbar J, Reid C: An exploration of issues of management and intention to stay: allied health professionals in South West Victoria, Australia. J Allied Health 2006, 35(4):226-232

7. Shanahan M: Radiographers and the internet: an Australian perspective. Radiol Technol 2010, 81(3):223-232.

8. Bloom BS: Effects of continuing medical education on improving physician clinical care and patient health: a review of systematic reviews. Int J Technol Assess Health Care 2005, 21(3):380-385.

9. Davis DA, Thomson MA, Oxman DD, Haynes RB: Changing physician performance. A systematic review of the effect of continuing medical education strategies. JAMA 1995, 274(9):700-705.

10. Firmstone VR, Elley KM, Skyhant MT, Fry-Smith A, Bayliss S, Torgerson CJ: Systematic review of the effectiveness of continuing dental professional development on learning, behavior, or patient outcomes. J Dent Educ 2013, 77(3):300-315.

11. Bluestone J, Johnson P, Fullerton J, Carr C, Alderman J, BonTempo J: Effective in-service training design and delivery: evidence from an integrative literature review. Hum Resour Health 2013, 11:51.

12. Farnan JN, Petty LA, Georgitis E, Martin S, Chiu E, Prochaska M, Arora VM: A systematic review: the effect of clinical supervision on patient and residency education outcomes. Acad Med 2012, 87(4):428-442.
13. Sambunjak D, Straus SE, Marusic A: Mentoring in academic medicine: a systematic review. JAMA 2006, 296(9):1103-1115.

14. Doorenbos AZ, Kundu A, Eaton LH, Demiris G, Haozous EA, Towle C, Buchwald D: Enhancing access to cancer education for rural healthcare providers via telehealth. J Cancer Educ 2011, 26(4):682-686.

15. Brownlee K, Graham JR, Doucette E, Hotson N, Halverson G: Have communication technologies influenced rural social work practice? $\mathrm{Br} J$ Soc Work 2010, 40(2):622-637.

16. Cameron D, McLean M, Namazi M: Recruitment and retention plan to improve access to occupational therapy, physiotherapy and speech lanquage pathology services for preschool children. Vancouver, BC: British Columbia Centre for Ability; 2001.

17. Roots RK, Li LC: Recruitment and retention of occupational therapists and physiotherapists in rural regions: a meta-synthesis. BMC Health Serv Res 2013, 13:59.

18. Curran V, Rourke L, Snow P: A framework for enhancing continuing medical education for rural physicians: a summary of the literature. Med Teach 2010, 32(11):e501-e508.

19. World Health Organisation: Increasing access to health workers in remote and rural areas through improved retention. Geneva; 2010.

20. Humphreys JS, Kuipers P, Wakerman J, Wells R, Jones A, Kinsman LD: How far can systematic reviews inform policy development for 'wicked' rural health service problems? Aust Health Rev 2009, 33:592-600.

21. Whittemore R, Kanfl K: The integrative review: updated methodology. Int $J$ Nurs Stud 2005, 52(5):546-553.

22. Kamien M: Staying in or leaving rural practice: 1996 outcomes of rural doctors' 1986 intentions. Med J Aust 1998, 169:318-321.

23. Humphreys JS, Wakerman J, Wells R, Kuipers P, Jones J, Entwistle P, Harvey P. Improving primany health care workforce retention in small rural and remote communities: how important is ongoing education and training? Australian Primary Health Care Research Institute: Canberra; 2007.

24. Hall F, Bell K: Professional support framework: improving access to professional support for professionals. Aust Health Rev 2013, 37:560-565.

25. Australian Institute of Health and Welfare: Rural, regional and remote health: a guide to remoteness classifications. Canberra; 2004.

26. Booth A: 'Brimfull of STARLITE': toward standards for reporting literature searches. J Med Libr Assoc 2004, 94(4):421-429.

27. Pawson R, Tilley N: Realistic Evaluation. London: Sage; 1997.

28. Daly J, Willis K, Small R, Green J, Welch N, Kealy M, Hughes E: A hierarchy of evidence for assessing qualitative research. J Clin Epidemiol 2007, 6:43-49.

29. National Health and Medical Research Council: NHMRC additional levels of evidence and grades for recommendations for developers of guidelines. Canberra; 2009.

30. Baxter S, Killoran A, Kelly MP, Goyder E: Synthesizing diverse evidence: the use of primary qualitative data analysis methods and logic models in public health reviews. Publ Health 2010, 124(2):99-106.

31. Mays N, Pope C, Popay J: Systematically reviewing qualitative and quantitative evidence to inform management and policy-making in the health field. J Health Serv Res Pol 2005, 10(suppl 1):6-20.

32. Ritchie J, Spencer L: Qualitative data analysis for applied policy research. In The Qualitative Researcher's Companion. Edited by Huberman M, Miles MB. California: Sage Publications; 2002:305-329.

33. Lynch L, Happell B: Implementing clinical supervision: part 1: laying the ground work. Int J Ment Health Nurs 2008, 17(1):57-64.

34. Lynch L, Happell B: Implementation of clinical supervision in action: part 2: implementation and beyond. Int J Ment Health Nurs 2008, 17(1):65-72.

35. English M, Nzinga J, Mbindyo P, Ayieko P, Irimu G, Mbaabu L: Explaining the effects of a multifaceted intervention to improve inpatient care in rural Kenyan hospitals - interpretation based on retrospective examination of data from participant observation, quantitative and qualitative studies. Implement Sci 2011, 6:124.

36. Xavier K, Shepherd L, Goldstein D: Clinical supervision and education via videoconference: a feasibility project. J Telemed Telecare 2007, 13(4):206-209.

37. Conger MM, Plager KA: Advanced nursing practice in rural areas: connectedness versus disconnectedness. Online J Rural Nurs Health Care 2008, 8(1):24-38 
38. Teasley SL, Sexton KA, Carroll CA, Cox KS, Riley M, Ferriell K: Improving work environment perceptions for nurses employed in a rural setting. J Rural Health 2007, 23(2):179-182

39. Cameron PJ, Este DC, Worthington CA: Professional, personal and community: 3 domains of physician retention in rural communities. Can J Rural Med 2012, 17(2):47-55.

40. Healey-Ogden M, Wejr P, Farrow C: British Columbia: improving retention and recruitment in smaller communities. Nurs Leader (Toronto, Ont) 2012, 25:37-44.

41. Arora S, Kalishman S, Thornton K, Dion D, Murata G, Deming P, Parish B, Brown J, Komaromy M, Colleran K, Bankhurst A, Katzman J, Harkins M, Curet $L$, Cosgrove E, Pak W: Expanding access to hepatitis $C$ virus treatment - extension for community healthcare outcomes (ECHO) project: disruptive innovation in specialty care. Hepatology 2010, 52(3):1124-1133.

42. Bennett-Levy J, Hawkins R, Perry H, Cromarty P, Mills J: Online cognitive behavioural therapy training for therapists: outcomes, acceptability, and impact of support. Aust Psychol 2012, 47(3):174-182.

43. Blattner K, Nixon G, Jaye C, Dovey S: Introducing point-of-care testing into a rural hospital setting: thematic analysis of interviews with providers. J Prim Health Care 2010, 2(1):54-60.

44. Brambila C, Lopez F, Garcia-Colindres J, Donis MV, Brambila C, Lopez F, Garcia-Colindres J, Donis MV: Improving access to services and interactions with clients in Guatemala: the value of distance learning. J Fam Plann Reprod Health Care 2005, 31(2):128-131.

45. Buckley KM, Adelson LK, Agazio JG, Buckley KM, Adelson LK, Agazio JG: Reducing the risks of wound consultation: adding digital images to verbal reports. J Wound Ostomy Continence Nurs 2009, 36(2):163-170.

46. Church EA, Heath OJ, Curran VR, Bethune C, Callanan TS, Cornish PA: Rural professionals' perceptions of interprofessional continuing education in mental health. Health Soc Care Community 2010, 18(4):433-443.

47. Cunningham D, Fitzpatrick B, Kelly D: Administration and clerical staff perceptions and experiences of protected learning time: a focus group study. Qual Prim Care 2006, 14(3):177-184

48. D'Souza R: A pilot study of an educational service for rural mental health practitioners in South Australia using telemedicine. J Telemed Telecare 2000, 6(0 suppl):187-189.

49. Ellis IK, Philip T: Improving the skills of rural and remote generalists to manage mental health emergencies. Rural Remote Health 2010, 10(3):1503.

50. Glazebrook R, Manahan D, Chater AB: Evaluation of an ultrasound program (intermediate obstetric and emergency medicine) for Australian rural and remote doctors. Aust J Rural Health 2005, 13(5):295-299.

51. Gorsche RG, Woloschuk W: Rural physicians' skills enrichment program: a cohort control study of retention in Alberta. Aust J Rural Health 2012, 20(5):254-258

52. Haythornthwaite S: Videoconferencing training for those working with at-risk young people in rural areas of Western Australia. $J$ Telemed Telecare 2002, 8:29-33.

53. King M, Munt R, Eastwood A: The impact of a postgraduate diabetes course on the perceptions Aboriginal health workers and supervisors in South Australia. Contemp Nurse: J Aust Nurs Prof 2007, 25(1-2):82-93.

54. Kelley ML, Habjan S, Aegard J: Building capacity to provide palliative care in rural and remote communities: does education make a difference? J Palliat Care 2004, 20(4):308-315.

55. Koczwara B, Francis K, Marine F, Goldstein D, Underhill C, Olver I: Reaching further with online education? The development of an effective online program in palliative oncology. J Cancer Educ 2010, 25(3):317-323.

56. Newman C, Martin E, McGarry DE, Cashin A, Newman C, Martin E, McGarry DE, Cashin A: Survey of a videoconference community of professional development for rural and urban nurses. Rural Rem Health 2009, 9(2):1134.

57. Schoo AMM, Stagnitti KE, Kevin PM: The evolution of a state-wide continuing education programme for allied health professionals. Int J Ther Rehabil 2008, 15(2):60-66.

58. White CD, Willett K, Mitchell C, Constantine S, White CD, Willett K, Mitchell C, Constantine S: Making a difference: education and training retains and supports rural and remote doctors in Queensland. Rural Rem Health $2007,7(2): 700$
59. Wright A, Ryan M, Haigh C, Sunderji I, Vijayakumar P, Smith C, Nestel D: Supporting international medical graduates in rural Australia: a mixed methods evaluation. Rural Rem Health 2012, 12(1):1-18.

60. Butcher MK: Improving access to quality diabetes education in a rural state: the Montana quality diabetes education initiative. Diabetes Educ 2006, 32(6):963-967.

61. Gibb H, Anderson J, Forsyth K: Developing support for remote nursing education through workplace culture that values learning. Aust J Rural Health 2004, 12(5):201-205.

62. Dalton L, Bull R, Taylor S, Galbraith K, Marriott J, Howarth H: Evaluation of the national pharmacy preceptor education program. Aust J Rural Health 2007, 15(3):159-165.

63. Gardner A, Smyth W, Renison B, Cann T, Vicary M: Supporting rural and remote area nurses to utilise and conduct research: an intervention study. Collegian 2012, 19(2):97-105.

64. Hoon EA, Newbury JW, Chapman P, Price J: Education to improve cancer care in rural South Australia. Rural Rem Health 2009, 9(2):1147.

65. MacKinnon K: Learning maternity: the experiences of rural nurses. Can $J$ Nurs Res 2010, 42(1):38-55.

66. Mitchell J, Robinson P, Seiboth C, Koszegi B: An evaluation of a network for professional development in child and adolescent mental health in rural and remote communities. J Telemed Telecare 2000, 6(3):158-162.

67. Owen C, Tennant C, Jessie D, Jones M, Rutherford V: A model for clinical and educational psychiatric service delivery in remote communities. Aust NZ J Psychiatry 1999, 33(3):372-378.

68. Schopp LH, Johnstone B, Reid-Arndt S: Telehealth brain injury training for rural behavioral health generalists: supporting and enhancing rural service delivery networks. Prof Psychol Res Pract 2005, 36(2):158-163.

69. Sullivan MP, Parenteau P, Dolansky D, Leon S, Le Clair JK: Shared geriatric mental health care in a rural community. Can J Rural Med 2007, 12(1):22-29.

70. Tumosa N, Horvath KJ, Huh T, Livote EE, Howe JL, Jones LI, Kramer BJ: Health care workforce development in rural America: when geriatrics expertise is 100 miles away. Gerontol Geriatr Educ 2012, 33(2):133-151.

71. Gagnon S, Minguet C: The Internet: an alternative to face-to-face training for teachers in remote locations? Can Fam Physician 2008, 54(8):1129.

72. Stewart S, Carpenter C: Electronic mentoring: an innovative approach to providing clinical support. Int J Ther Rehabil 2009, 16(4):199-206.

73. Chipps J, Ramlall S, Mars M: Videoconference-based education for psychiatry registrars at the University of KwaZulu-Natal, South Africa. Afr J Psychiatr 2012, 15(4):248-254.

74. Chipps J, Brysiewicz P, Mars M: A systematic review of the effectiveness of videoconference-based tele-education for medical and nursing education. Worldviews Evid Based Nurs 2012, 9(2):78-87.

75. Dunbar J, Reddy P, MCAvoy BR, Carter RC, Schoo AM, Colgan SJ, Weller DP, Torneus I: The contribution of approaches to organisational change in optimising the primary health care workforce. Canberra: Australian Primary Health Care Research Institute; 2007

76. Nancarrow SA, Roots A, Grace S, Moran AM, Vanniekerk-Lyons K: Implementing large scale workforce change: learning from 55 pilot sites of allied health workforce redesign in Queensland, Australia. Human Res Health 2013, 11:66.

\section{doi:10.1186/1478-4491-12-10}

Cite this article as: Moran et al:: Supervision, support and mentoring interventions for health practitioners in rural and remote contexts: an integrative review and thematic synthesis of the literature to identify mechanisms for successful outcomes. Human Resources for Health 2014 12:10 